\title{
Thymoquinone, as a Novel Therapeutic Candidate of Cancers
}

\author{
Belal Almajali ${ }^{1}$, Hamid Ali Nagi Al-Jamal ${ }^{1, * \mathbb{C}}$, Wan Rohani Wan Taib ${ }^{1}$, Imilia Ismail ${ }^{1}$ (D), \\ Muhammad Farid Johan ${ }^{2}\left[\right.$, Abd Almonem Doolaanea ${ }^{3}\left[\right.$ and Wisam Nabeel Ibrahim ${ }^{4}(\mathbb{D}$ \\ 1 School of Biomedicine, Faculty of Health Sciences, Universiti Sultan Zainal Abidin (UniSZA), \\ Terengganu 21300, Malaysia; bel_basss@yahoo.com (B.A.); wanrohani@unisza.edu.my (W.R.W.T.); \\ imilia@unisza.edu.my (I.I.) \\ 2 Department of Haematology, School of Medical Sciences, Universiti Sains Malaysia, Kubang Kerian, \\ Kelantan 16150, Malaysia; faridjohan@usm.my \\ 3 Department of Pharmaceutical Technology, Faculty of Pharmacy, International Islamic University Malaysia, \\ Kuantan 25594, Malaysia; monem@iium.edu.my \\ 4 Department of Biomedical Sciences, College of Health sciences, QU Health, Qatar University, \\ Doha 2713, Qatar; w.ibrahim@qu.edu.qa \\ * Correspondence: aljamalhamid@unisza.edu.my; Tel.: +60-174729012
}

Citation: Almajali, B.;

Al-Jamal, H.A.N.; Taib, W.R.W.;

Ismail, I.; Johan, M.F.;

Doolaanea, A.A.; Ibrahim, W.N.

Thymoquinone, as a Novel

Therapeutic Candidate of Cancers.

Pharmaceuticals 2021, 14, 369.

https://doi.org/10.3390/ph14040369

Academic Editor: Thomas Efferth

Received: 11 March 2021

Accepted: 13 April 2021

Published: 16 April 2021

Publisher's Note: MDPI stays neutral with regard to jurisdictional claims in published maps and institutional affiliations.

Copyright: (C) 2021 by the authors. Licensee MDPI, Basel, Switzerland. This article is an open access article distributed under the terms and conditions of the Creative Commons Attribution (CC BY) license (https:// creativecommons.org/licenses/by/ $4.0 /)$.

\begin{abstract}
To date, natural products are widely used as pharmaceutical agents for many human diseases and cancers. One of the most popular natural products that have been studied for anticancer properties is thymoquinone (TQ). As a bioactive compound of Nigella sativa, TQ has shown anticancer activities through the inhibition of cell proliferation, migration, and invasion. The anticancer efficacy of TQ is being investigated in several human cancers such as pancreatic cancer, breast cancer, colon cancer, hepatic cancer, cervical cancer, and leukemia. Even though TQ induces apoptosis by regulating the expression of pro- apoptotic and anti-apoptotic genes in many cancers, the TQ effect mechanism on such cancers is not yet fully understood. Therefore, the present review has highlighted the TQ effect mechanisms on several signaling pathways and expression of tumor suppressor genes (TSG). Data from relevant published experimental articles on TQ from 2015 to June 2020 were selected by using Google Scholar and PubMed search engines. The present study investigated the effectiveness of TQ alone or in combination with other anticancer therapeutic agents, such as tyrosine kinase inhibitors on cancers, as a future anticancer therapy nominee by using nanotechnology.
\end{abstract}

Keywords: thymoquinone; cancers; proliferation; apoptosis; angiogenesis; nanoparticle

\section{Introduction}

Thymoquinone (TQ) is one of the bioactive constituents in Nigella sativa (N. sativa), black seed, or Alhabba Al-Sauda [1]. TQ and other N. sativa components such as $\alpha$-pinene, p-cymene, and monoterpenes have been used as an antineoplastic, antioxidant, analgesic, and anti-inflammatory agent [2]. It has shown effectiveness against several diseases, such as liver diseases [3] and brain disorders, like Parkinson's [4] and Alzheimer's diseases [5]. TQ enhances the immune system and prevents oxidative damage of healthy cells [6]. TQ has shown different anticancer activities through cell proliferation inhibition, apoptosis induction, or interference with other tumorigenic processes, such as cell migration, invasion, and altering epigenetic events alteration in cancer cells $[7,8]$. TQ selectively inhibits the cancer cells' proliferation in leukemia [9], breast [10], lungs [11], larynx [12], colon [13,14], and osteosarcoma [15]. However, there is no effect against healthy cells [16]. TQ also demonstrates antitumor properties by regulating different targets, such as nuclear factor kappa B (NF-Kb), peroxisome proliferator-activated receptor- $\gamma$ (PPAR $\gamma)$, and c-Myc [1], which resulted in caspases protein activation [17]. It also re-expressed tumor suppressor genes (TSG), such as p53 and Phosphatase and tensin homolog (PTEN) in lung cancer [18]. In the present study, data from more than 60 relevant published experimental articles on TQ effects individually or combined with other compounds, on cancers between January 
2015 to June 2020 were included by using Google Scholar and PubMed search engines. Books, chapters or review articles published were excluded.

\section{Properties and Pharmacological Features of TQ}

The active composition in $N$. sativa includes TQ, thymol, thymohydroquinone, carvacrol, dithymoquinone (nigellone), nigellidine, hedrin, and nigellicine. The percentage of TQ in the volatile oil of N. sativa is about $25 \%$ and thus it is attributed to the therapeutic effect [19]. TQ is found in tautomeric forms as in keto form (90\%) and enol form or mixtures [20]. Due to hydrophobicity, there are limitations in the bioavailability and drug formation of TQ. Moreover, TQ solubility depends on duration, which is from $549 \mu \mathrm{g} / \mathrm{mL}$ to $669 \mu \mathrm{g} / \mathrm{mL}$ in aqueous solutions at $24 \mathrm{~h}$, to $665-740 \mu \mathrm{g} / \mathrm{mL}$ at $72 \mathrm{~h} \mathrm{[21].} \mathrm{To} \mathrm{overcome}$ these obstacles, scientists are looking to use TQ-based nanotechnology and synthesize novel TQ analogs with more effectiveness and bioavailability. Synthetic TQ analogs with their effects on diseases are shown in Table 1. The administration of TQ includes oral subacute, subchronic, intraperitoneal, and intravenous [22]. In oral administration, liver enzymes could cause biotransformation because the metabolizing activity reduces TQ into hydroquinone [23]. The median lethal dose $\left(\mathrm{LD}_{50}\right)$ of oral and interperitoneal administration for rats was reported as $790 \mathrm{mg} / \mathrm{kg}$ and $57 \mathrm{mg} / \mathrm{kg}$, respectively, while signs of toxicity at high doses were hypoactivity and difficulty of respiration [24]. In several studies, researchers have intraperitoneally injected rats and mice with doses between $5 \mathrm{mg} / \mathrm{kg}$ and $12.5 \mathrm{mg} / \mathrm{kg}$ without toxicity [25]. Other studies showed that an oral dose of $100 \mathrm{mg} / \mathrm{kg}$ or less of TQ did not have any toxic effect [26]. TQ is sensitive to light; a short period of exposure results in severe degradation, regardless of the solution's acidity and solvent type [27]. It is also unstable in alkaline solutions because TQ's stability decreases with rising $\mathrm{pH}$ [21]. Protein-drug interactions have an essential role in the pharmacological properties of drugs. The measured percentages of TQ-protein binding in rabbit and human plasma were 99.19 and 98.99 , respectively, which means that TQ is a compound with quick elimination and relatively slow absorption after oral administration [22].

By studying TQ and human serum albumin (HSA) interactions, results showed that the association of TQ with HSA did not affect the secondary structure of HSA. Moreover, the HSA/TQ thermodynamic analysis reported that the binding process occurred spontaneously, and the hydrophobic interactions were the principal intermolecular forces that stabilize the complex [28]. Studies on the effects of binding bovine serum albumin (BSA) and $\alpha 1$-acid glycoprotein (AGP) on TQ showed that TQ bound to AGP has no changes in its anticancer activity, while TQ bound to BSA loses its activity because of covalent binding [29]. Bioavailability and stability of TQ and formulation problems delay the use of TQ medicinally, which calls for intensified research to overcome these difficulties.

Table 1. Some analogs have been developed for enhanced bioavailability and activity of TQ.

\begin{tabular}{cccc}
\hline Type & Disease Models & References \\
\hline sulfur-containing TQ-analogs & radiation-induced dyslipidemia in rats & [30] & [31] \\
\hline nitrogen-substituted TQ analogues & human ovarian cancer cell lines & antifungal effect against Candida albicans, Saccharomyces & cerevisiae and Aspergillus brasiliensis \\
\hline 3-aminothymoquinone & [32] & \\
\hline
\end{tabular}

\section{TQ and Nanotechnology}

TQ nanoparticle research aims to improve TQ's pharmaceutical effects, such as targeting capacity, bioavailability, and avoiding unspecific binding. Different formulations of TQ nanoparticles were tested against several types of cancer, whereby the studies showed greater effectiveness of TQ nanoparticle than free TQ [33]. These formulations included nanostructured lipid carriers (NLCs), solid lipid nanocarriers (SLNs), polymeric, niosomal, and liposomal. 


\subsection{Polymeric TQ Nanoparticles}

Polymeric nanoparticle formulation has several advantages, making it suitable for drug delivery. The nanoparticles are smaller than cells, stable in blood, nontoxic, improve biodegradability, and control the release of drugs [34]. They are approved by the FDA and can be formulated by many techniques, depending on the drug (Figure 1A). As such, there are many types of polymeric nanoparticles that are used for drug encapsulation. The poly-lactide-co-glycolide (PLGA) nanoparticle is the most abundant polymer formulation used in the nanomedical field. It is relatively nontoxic because it can be transformed into degradable lactic acid and glycolic acid, and can be removed as water and carbon dioxide after the metabolizing process [35]. Mixing PLGA formulations with chitosan, pectin, and alginate can improve transportation across mucosal barriers and enhance drug delivery [36]. TQ-PLGA nanoparticles are prepared by using acetone-dissolved polymer, with or without emulsifier or stabilizer [34]. It is shown to be more effective than free TQ. The $50 \%$ inhibitory concentration $\left(\mathrm{IC}_{50}\right)$ for free $\mathrm{TQ}$ was $0.132 \pm 0.003 \mathrm{mg} / \mathrm{mL}$ compared to $0.030 \pm 0.002 \mathrm{mg} / \mathrm{mL}$ for TQ loaded PLGA nanoparticles against breast cancer cell lines [37]. Polyethylene glycol (PEG) nanoparticles are nontoxic and water-soluble polymers [33], which are used to encapsulate many drugs, like doxorubicin (DOX) [38]. TQ has been encapsulated in PEG nanoparticles by the nanoprecipitation method, inhibiting cancer cells' migration in the breast cancer cell line [33]. PEG formulation is also a safe carrier for hydrophobic drugs, such as TQ, with a nontoxic effect on the rat's neuronal hippocampal cells with $97.5 \%$ drug-loading efficiency [39]. All of the above make PEG nanoparticles preferable over others for TQ encapsulation. As such, it could be useful for

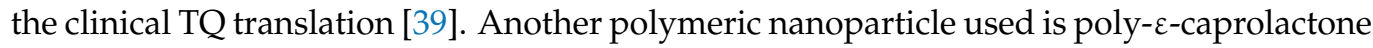
(PCL), which is biodegradable polyester [34]. TQ encapsulation with PCL exhibited higher encapsulation rates and higher entrapment efficiency than PLGA (88\%). PCL-TQ-loaded nanoparticles were tested in vivo to treat colorectal tumors in murine models. The mice were injected with C26 cells to induce tumor formation. Then, PCL-TQ or TQ solutions $(0.5 \mathrm{mg} / \mathrm{mL}$ in PBS) were injected twice a week until the tumor's average volume exceeded $2000 \mathrm{~mm}^{3}$. The results showed significantly higher therapeutic activity of PCL-TQ that was described by higher survival rates and reduced tumor volume as compared to free TQ [40]. Furthermore, cyclodextrin (CD) is used for encapsulation with two surfaces, which are external hydrophilic and internal hydrophobic. CD has low toxicity, prevents degradation of conjugated drugs, and is available in different sizes [41]. The self-assembly method is used to conjugate TQ with CD, whereby TQ mixed with b-CD in a specific ratio (4 TQ-1 CD) improved TQ's antiproliferative properties and showed activity against MCF-7 breast cancer cells in a time-dependent manner; the $\mathrm{IC}_{50}$ decreased five times as compared with free TQ. Despite the promising results, TQ-CD needs further studies, especially on the safety aspect, to reach the clinic as soon as possible [42].

\subsection{Lipid-Based TQ Nanoparticles}

In recent decades, lipid-based nanoparticles (LNPs) (Figure 1B) had received great attention as a nanoscale delivery system to enhance the oral bioavailability of poorly absorbed bioactive compounds for health improvement. However, scientific studies on the biological fate of orally administered LNPs are limited, and absorption mechanisms through the intestinal lumen into the circulation remain unclear [43]. Liposomes are the earliest models of developed lipid-based carriers described as nontoxic, biocompatible, flexible, and fully biodegradable [44]. They are essentially composed of phospholipid bilayer vesicles, including phosphatidylcholine and phosphatidylethanolamine, the most popular phospholipids found in nature, with other membrane bilayer components, such as cholesterol and hydrophilic polymers around each liposomal vesicle [45]. A TQ-loaded liposome (TQ-LP) with entrapment efficiency of $90 \%$ was prepared by using the conventional thinfilm hydration technique via 1,2-dipalmitoyl-sn-glycero-3-phosphocholine phospholipids showing cytotoxicity against T47D and MCF-7 breast cancer cell lines with little effect on the normal cells [46]. Niosomes are another lipid carrier formed in an aqueous medium 
from the self-assembly of nonionic surfactants, resulting in closed bilayer structures [47]. They have favorable properties such as biodegradability, biocompatibility, and nontoxic nature [48]. Encapsulated TQ in niosomes containing TQ and Akt-siRNA (siRNA-Nio-Au$\mathrm{TQ}$ ), with $82 \%$ TQ-loading efficiency, was tested against tamoxifen-resistant (MCF-7/Tam and T-47D/TAM) and Akt-overexpressing (MCF-7/Akt) cells and in vivo in a BALB/c (nu+/nu+) xenograft mouse model of MCF-7/TAM. In all experiments, TQ nanoparticles showed better effects in reducing cellular levels of Akt and significant decreasing tumor mass and volume compared to free TQ [49]. This innovative method holds promise for TQ targeted delivery and maintenance of sufficient TQ concentrations for a sustained period. Recently, solid lipid nanostructures (SLNs) developed from solid lipids had better control over drug delivery and release [50]. Releasing encapsulated TQ in SLNs is performed via rapid release and then through slow controlled release [51]. The in vivo study showed TQ-SLN in plasma of rats increased five-fold after oral administration, as compared to free TQ. On the other hand, TQ-SLN formulation exhibited in vitro controlled drug release ability, with the highest release of $70 \%$, as compared to $47 \%$ for free TQ. Additionally, the amount of TQ in vital organs like the heart, lungs, spleen, brain, liver, and kidneys was higher upon SLN administration [52].

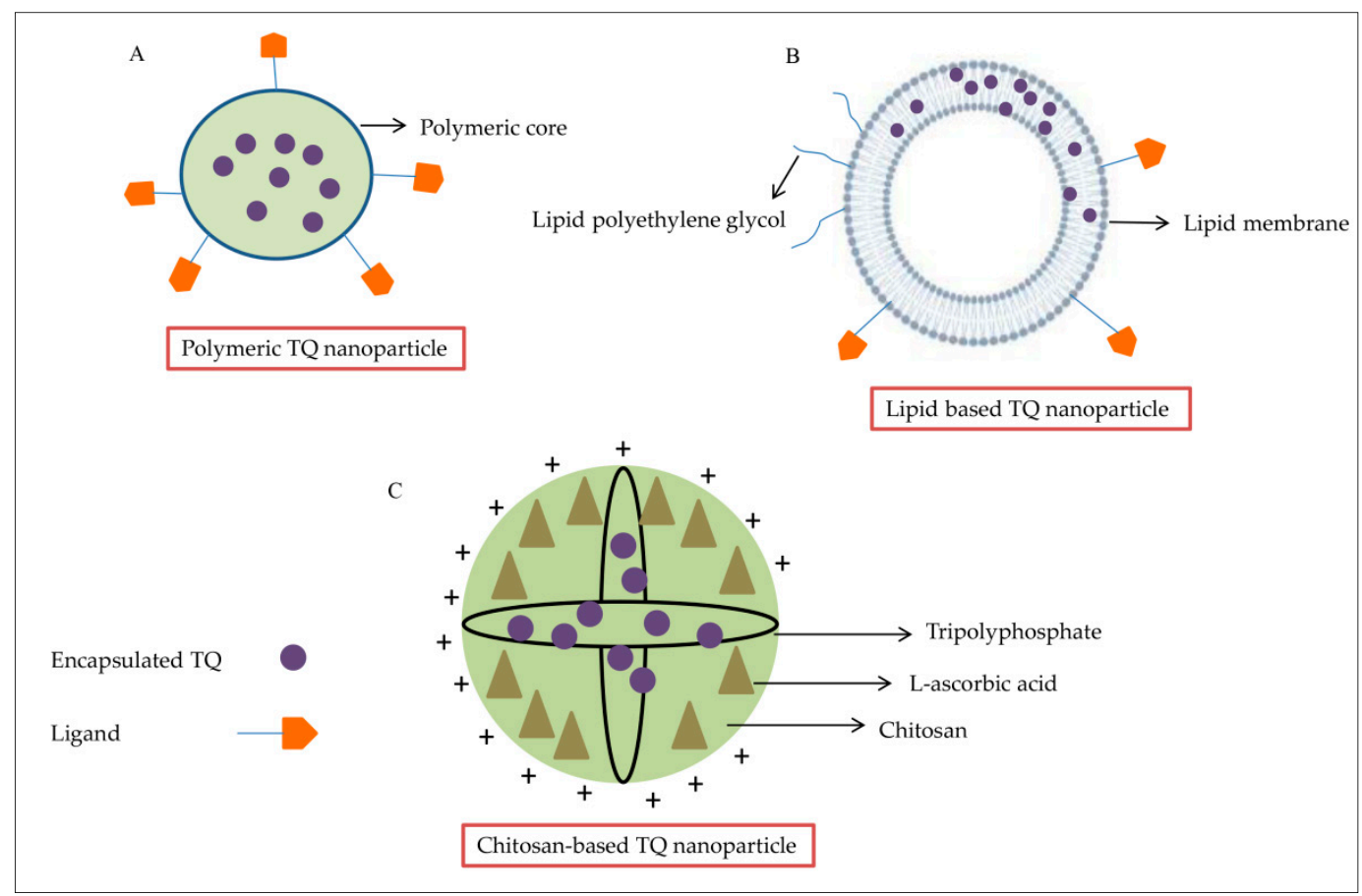

Figure 1. TQ encapsulated in different nanoparticle formulations. (A) TQ entrapped within the polymeric core of a polymeric nanoparticle. (B) Structure of lipid nanoparticle containing TQ sandwiched between two layers of charged ionizable lipids. (C) The chitosan nanoparticle typically possesses positive surface charges and mucoadhesive properties that can adhere to mucus membranes and release TQ in a sustained release manner.

\subsection{Chitosan-Based TQ Nanoparticles}

Chitosan (CS) is a modified biopolymer derived from chitin (Figure 1C). It is a whitecolor, inflexible, and inelastic polysaccharide. Chitosan is used in many applications, such as water treatment, biomedical industries, and agriculture, because it is antimicrobial, biodegradable, and nontoxic [53,54]. Encapsulating TQ with CS improves the uptake and bioavailability of TQ but has low encapsulation efficiency (35\%) [55]. Two formulations of CS were used with TQ, TQ-CS, and TQ-myristic acid-CS (TQ-MA-CS) [56]. The TQ-CS showed the same pattern as TQ-SLN, a rapid initial release followed by a slow release, and thus improved the continued release of TQ from the nanoparticle. TQ-CS exhibited better penetration with higher targeting of the brain upon intravenous administration [36]. 


\section{Anti-Cancer Effects of TQ}

\subsection{Breast Cancer}

Breast cancer is one of the most prevalent cancers among females, with high mortality incidence, especially in advanced cases. It was shown that TQ with piperine inhibited the proliferation of breast cancer cells through apoptosis induction, angiogenesis inhibition, and immune system stimulation [57]. TQ has also affected breast cancer by targeting the PPAR$\gamma$ pathway and inhibiting the migration and invasion of cancer cells [58]. Furthermore, TQ showed antiproliferative and pro-apoptotic potency on breast cancer through the suppression of anti-apoptotic proteins, such as survivin, Bcl-xL, and Bcl-2 [59].

Fatfat et al. (2019) found that treating doxorubicin-resistant MCF-7/DOX cells with TQ inhibited Akt and Bcl2 phosphorylation and increased the expression of PTEN and apoptotic regulators such as Bax, cleaved PARP, cleaved caspases, p53, and p21 [60]. The intraperitoneally injection of the breast cancer mouse model with 2 or $4 \mathrm{mg} / \mathrm{kg}$ of TQ for four weeks repressed tumor growth and inhibited metastasis with significant inhibition of chemokine receptor Type 4 (CXCR4), which is considered a poor prognosis indicator, matrix metallopeptidase 9 (MMP9), vascular endothelial growth factor Receptor 2 (VEGFR2), Ki67, and cyclooxygenase-2 (COX2) expression [61]. A thymoquinone-loaded hyaluronic acid-conjugated pluronic nanoparticle (HA-TQ-NPs) showed a high efficiency against triple-negative breast cancer (TNBC), as well as having no effect on healthy cells. Moreover, HA-TQ-NPs upregulated the miRNA-361, which in turn downregulated Rac1 and RhoAmediated cell migration. In addition to inhibiting cancer metastasis by decreasing the secretion of VEGF-A [62], TQ $(20 \mu \mathrm{M})$ also inhibits the eukaryotic elongation Factor 2 kinase eEF-2K, which has a central role in TNBC tumor proliferation and progression by regulating the activity of pathways, such as Src, FAK, PI3K/Akt, c-Myc, and cyclin D1 [63]. A combination of TQ-chemotherapy medication (paclitaxel), TQ-PTX, and upregulated TSGs such as Brca1, Hic1, and p21, induced the apoptosis protein levels caspase-3, caspase-7, and caspase-12. It also reduced the phosphorylated p65 and Akt1 proteins in the 4T1 mouse breast cancer cell lines at 1.3 $\mu \mathrm{M}$ [64]. TQ enhanced apoptosis in MCF7 and T-47D human breast cancer cell lines by upregulating p53 and downregulating the regulator MDM2. It also silenced Akt expression to reduce the acquired resistance [49].

\subsection{Lung Cancer}

Lung cancer is one of the most common cancers that cause tumor-related deaths worldwide [65]. Yang et al. (2015) reported that TQ (10, 20, $40 \mu \mathrm{M})$ inhibited growth and reduced expression of the proliferation marker cyclin D1 in the A549 non-small lung cancer cell line. It also showed the ability to suppress the ERK1/2 signaling pathway, which inhibited the migration and invasion of A549 cells [66]. TQ combined with a developed delivery system (TQ-phytosome) induced apoptosis at $4.31 \pm 2.21 \mu \mathrm{M}$ via the activation of caspase-3 and generation of reactive oxygen species (ROS), in addition to accumulating cells on G2-M and pre-G1 phases in the A549 cell line [67]. TQ enhanced apoptosis by increasing the Bax/Bcl2 ratio and upregulating the p53 expression in A549 cells [11] and mice [68]. Subcutaneous doses of TQ-indirubin-3-monoxime (TQ-I3M) combination suppressed the lung cancer metastasis and reduced tumor growth through the inhibition of Akt/mTOR/NFKB signaling in the xenograft mouse model. The administrated doses, low dose of 5 and $3 \mathrm{mg} / \mathrm{kg}$ and high dose of 10 and $6 \mathrm{mg} / \mathrm{kg}$ of TQ and I3M, respectively, were well tolerated by the animals and caused no significant changes in the body weight or apparent mortality, which indicated the safety of the used doses [69]. It is observed through many experiments that the combined treatment of TQ and anticancer drugs gives better results on cancer cells. It also reduces the toxicity of the chemotherapy dose and reduces its toxicity while ensuring a significant therapeutic effect (Table 2). TQ nanoparticle with transferrin (TF-TQ-NP) $5 \mu \mathrm{g} / \mathrm{mL}$ induces the expression of p53, miR-34a, and miR-16, while reducing Bcl2 expression, which elevates apoptosis percentage in the non-small cell lung cancer cells. TF-TQ-NP also inhibits cell migration by activating the p53/miR-34a axis. TF-TQ-Np did not generate any significant toxicity on the normal lung epithelial cell 
line (W138 cells) up to $15 \mu \mathrm{g} / \mathrm{mL}$ [18]. TQ activates the tumoricidal activity of natural killer (NK) against lung cancer cells by upregulating pro-apoptotic genes and downregulating anti-apoptotic genes [70].

Table 2. Mechanistic action of some anti-cancer drugs in combination with the TQ.

\begin{tabular}{cccc}
\hline Name of Drug & Action of Drug & References \\
\hline Cisplatin & Induction of DNA damage through Pt-mediated DNA crosslinking & (Alkylating-like mechanism) & [71] \\
\hline Temozolomide (TMZ) & DNA damage through alkylation and cell cycle arrest at G2/M phase & [72] \\
\hline Tamoxifen (TAM) & Anti-estrogens (compete with estrogen to bind with estrogen receptor) & [73] \\
\hline Topotecan (TP) & & Topoisomerase-I inhibitor & [74] \\
\hline Paclitaxel (Pac) & Interfere in mitotic spindle formation through stabilization of microtubule assembly & [64] \\
\hline Docetaxel & & Microtubule disrupting agent & [75] \\
\hline miR-34a & & MicroRNA & [76] \\
\hline
\end{tabular}

\subsection{Gastric Cancer}

TQ at 25, 50 and $75 \mu \mathrm{M}$ inhibited JAK2 and c-Src activity and induced apoptosis by inhibiting the phosphorylation of STAT3 and STAT3 downstream genes, such as Bcl-2, cyclin D, survivin, and VEGF, and upregulating caspases-3, caspases-7, and caspases-9 in gastric cancer cell lines HGC27 and BGC823 [17]. In a dose-dependent manner, TQ at 10 and $100 \mu \mathrm{M}$ inhibited proliferation and reduced the colony formation and migration of SGC7901 and MGC80-3 gastric cancer cell lines and downregulated the mesenchymal genes expression N-cadherin, vimentin, and TWIST, while upregulating epithelial genes like E-cadherin and cytokeratin-19. Furthermore, TQ suppressed the PI3K/Akt pathway and inhibited the phosphorylation of Akt and mTOR, hence inhibiting cancer progression [77]. The combined treatment of $5 \mu \mathrm{M}$ TQ and $2 \mu \mathrm{g} / \mathrm{mL}$ cisplatin was more effective in cancer growth and progression than either agent alone in a xenograft tumor mouse model. TQ pretreatment following cisplatin induced PTEN protein and inhibited p-AKT, CyclinD1, and P-glycoprotein (P-gp). Meanwhile, TQ and cisplatin also induced Bax, Cyt C, AIF, cleaved caspase-9, and cleaved caspase- 3 proteins, and inhibited Bcl-2, procaspase- 9 , and procaspase-3 [78].

\subsection{Colon Cancer}

In colon cancer cell lines, TQ has anti-tumorigenic effects through several mechanisms (Figure 2). A study conducted by Chen et al. (2015) by using an irinotecan-resistant (CPT11-R) LoVo colon cancer cell line showed that $2 \mu \mathrm{M}$ TQ induced apoptosis and activated mitochondrial outer membrane permeability (MOMP), inducing autophagic cell death at the beginning of autophagosome by triggering the autophagy proteins, such as JC-1, Atg5, Atg7, Atg12, LAMP2, Beclin-1, LC3, LC3-II, and SQSTM1/p62 [79]. TQ-artemisinin hybrid therapy $(2.6 \mu \mathrm{M})$ showed an enhanced ROS generation level and concomitant DNA damage induction in human colon cancer cells, while not affecting nonmalignant colon epithelial at $100 \mu \mathrm{M}[80]$.

TQ $(20 \mu \mathrm{M})$ had reduced proliferation by inhibiting p-PI3K, p-Akt, p-GSK3 $\beta$, and $\beta$-catenin, which suppressed the activation of prostaglandin receptors EP2 and EP4 in LoVo colon cancer cells. It also reduced the migration of colon cancer cells by reducing the expression of the COX-2 gene. Similar results were obtained in an animal tumor xenograft model [13]. TQ had repressed the metastasis in the irinotecan-resistant (CPT11-R) LoVo colon cancer cell line by inhibiting the phosphorylation of IKKa/b and NF-jB and activity of ERK1/2, as well as activating JNK and p38 [81]. According to a study by Zhang et al. (2016), 20, 40 and $60 \mu \mathrm{M}$ of TQ inhibited the phosphorylation of p65 in the nucleus and reduced c-Myc, Bcl-2, and VEGF expressions in COLO205 and HCT116 colon cancer cell lines. As a result, NF-Kb action was prevented, which was crucial in the 
proliferation of cancer cells [82]. In the in vivo study by Mohamed et al. (2017), $0.5 \mathrm{~mL} /$ day vitamin D and $35 \mathrm{mg} / \mathrm{kg} /$ day TQ were given individually or in combination 3 days/week orally, 4 weeks prior to colon cancer induction with azoxymethane, for 20 weeks. The results showed that the TQ-vitamin D3 combination significantly reduced pro-cancerous molecules (Wnt, $\beta$-catenin, NF- $\mathrm{kB}, \mathrm{COX}-2$, iNOS, VEGF and HSP-90) and more elevated anti-tumorigenesis biomarkers (DKK-1, CDNK-1A, TGF- $\beta 1$, TGF- $\beta /$ RII and smad4) as compared to individually treated groups [83]. The combination of $40 \mu \mathrm{M}$ TQ with $0.6 \mu \mathrm{M}$ Topotecan anticancer drug enhanced the action of the Topotecan and lowered its toxicity. A combined treatment inhibited the proliferation through upregulating p53 and elevating the Bax/Bcl2 ratio and increasing DNA damage in a human colon cancer cell line (HT-29) [74].

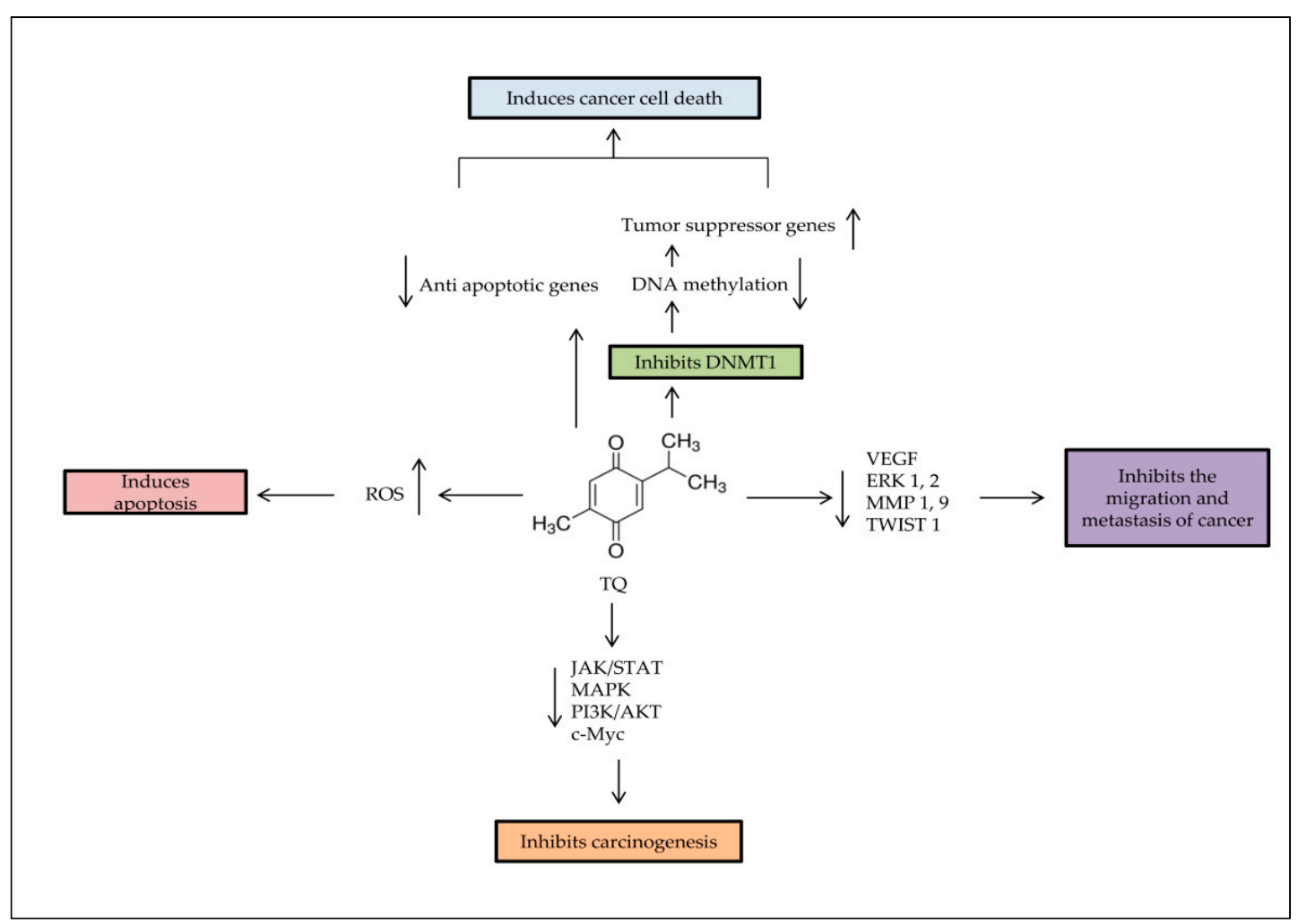

Figure 2. Major anti-tumorigenic properties of TQ. Apoptosis is induced by TQ in cancer cells through producing ROS, demethylating and re-expressing the TSG. TQ inhibits the survival signaling pathways to reduce carcinogenesis progress rate, and decreases cancer metastasis through regulation of epithelial to mesenchymal transition (EMT).

\subsection{Prostate Cancer}

Prostate cancer is the most deadly urogenital tumor in men [84]. TQ $(10 \mu \mathrm{M})$ inhibited the migration metastasis of prostate cancer by reducing the expression of epithelialmesenchymal transition (EMT) markers in DU145 and PC3 prostate cancer cell lines and reduced transforming growth factor beta (TGF- $\beta$ ), Smad2, and Smad3, which are essential intracellular signaling components [85]. TQ could be an effective inhibitor of the active sites of cytochrome $\mathrm{P} 450$ enzymes, which are considered as a significant target in prostate cancer therapy [86]. TQ-Docetaxel combination $(50 \mu \mathrm{M}+10 \mathrm{nM}$, respectively) increased apoptosis rate in DU145 and C4-2B prostate cancer cells by inhibiting the PI3K/AKT pathway and downstreaming signaling effectors. It has also induced pro-apoptotic proteins (BID and BAX) and procaspase-3, and inhibited the anti-apoptotic protein Bcl-xL [87].

An in vivo study conducted by Al-Trad et al. (2017) exhibited the possible protective effects of TQ against the development of benign prostatic hyperplasia (BPH) in six Wistar rats receiving $50 \mathrm{mg} / \mathrm{kg}$ orally for 14 days. The results showed TQ's ability to reduce prostate weight/body weight ratio, epithelial hyperplasia, serum interleukin 6 (IL-6) levels, 
and the expressions of TGF- $\beta 1$ and VEGF-A in the treated group [88]. TQ has suppressed prostate cancer's carcinogenesis at $45 \mu \mathrm{M}$ by reducing IL-6 expression and inhibiting the phosphorylation of STAT3, AKT, and extracellular signal-regulated kinase (ERK) proteins in PC3 prostate cancer cells [89].

\subsection{Skin Cancer}

TQ at $15 \mu \mathrm{M}$ has enhanced the apoptosis in the A-431 epidermoid carcinoma cell line by inducing the p53 and Bax expressions and caspase activation. It also reduced the Bcl-2, STAT3, and downstream genes survivin and cyclin D1's expressions, besides increasing cell death percentage through enhancing ROS generation and accumulation in treated cells. In the in vivo xenograft study, mice were subcutaneously injected with human epidermoid carcinoma A431 cells, then TQ was administered intraperitoneally $(5 \mathrm{mg} / \mathrm{kg})$ three times a week for 2 weeks. The results revealed that tumor growth was significantly delayed in TQ-treated mice compared to that in the control group [90]. A recent study by Jeong et al. (2020) showed the effectiveness of TQ (10, 15 and $20 \mu \mathrm{M})$ against proliferation, differentiation, and cell motility of the B16F10 mouse melanoma cell line. TQ reduced the expression of microphthalmia-associated transcription factor (MITF), tyrosinase expression, and tyrosinase activity, leading to the inhibition of the Wnt signaling pathway [91]. In the previous study, TQ has induced apoptosis by caspase-3 activation, inhibited the JNK pathway and prevented proliferation, angiogenesis, metastasis and invasion by enhancing chromatin condensation and DNA fragmentation in the A431, Hep2, and RPMI2650 skin cancer cell lines. It also inhibited the MAPK and PI3K/Akt pathways in KB Oral squamous cell carcinoma cells [22]. TQ $(4 \mu \mathrm{M})$ has reduced the proliferation and migration of KB oral squamous carcinoma cell line by inhibiting the activation of the PI3K/AKT signaling pathway [92]. In mice with intracerebral melanoma, the TQ-treated group lived longer than the untreated group (16 days vs. 9 days; $p=0.008$ ), TQ was given at a dose of $10 \mathrm{mg} / \mathrm{kg}$ via intra-peritoneal injection. While in vitro results showed that $60 \mu \mathrm{M}$ TQ inhibited p-STAT3, induced DNA fragmentation and apoptosis, and caused an increase in ROS molecules in B16-F10 [93]. A combination of TQ and Gamma Knife (GK), a treatment for melanoma brain metastasis, promoted GK's activity and induced apoptosis in B16-F10 cells by inhibiting p-STAT3. The treatment also exerted a lowering in the levels of tumor-related inflammatory cytokines [94].

\subsection{Ovarian Cancer}

Ten $\mu \mathrm{M}$ of TQ suppressed the invasion and migration of ovarian cells stimulated by lysophosphatidic acid (LPA), a growth factor presents in the tumor microenvironment (TME), besides inhibiting the downstream targets of LPA, such as JNK, Src, and FAK [95]. TQ $(6 \mu \mathrm{g} / \mathrm{mL})$ has reduced the permeability of plasma and mitochondrial membrane in the Caov-3 ovarian cancer cell line and decreased the nuclear area with a notable inhibition for both Bcl-2 and Bax, in addition to triggering the oxidative stress and increasing the apoptosis in ovarian cancer [14]. Another study has shown that the combination of TQ with cisplatin led to better results than when used separately, with a higher apoptosis rate and Bax/Bcl-2 ratio [96].

A recent study by İnce et al. (2020) reported that folic acid-chitosan-conjugated TQ nanoparticles (FA-TQ-CSNPs) increased the cytotoxicity of FA against SKOV3 cell lines compared to TQ, TQ-CS, and FA-TQ-CS [97]. Johnson et al. (2019) have investigated TQ analogs and found that the analogs showed modest improvement against ovarian cancer cell lines. Despite this, they highlighted the importance of studying TQ structure-activity, especially since a synthetic aminothymoquinone obtained by substituting the $\mathrm{CH}$ of the isopropyl group in TQ with a single nitrogen atom revealed a significant increase in water solubility and improved ovarian cancer drugs paclitaxel and carboplatin [98]. TQ-cisplatin combination increased DNA fragmentation and apoptosis, reduced proliferation, and inhibited the NF-KB tumor protein in the ID8-NGL ovarian cell line [71]. 


\subsection{Liver Cancer}

In the HepG2 human hepatocellular carcinoma cell line, different concentrations of TQ $(10,30$ and $50 \mu \mathrm{M})$ have notably reduced viability, induced apoptosis, and suppressed HepG2 cells' migration and invasion ability in a dose-dependent manner. It also reduced angiogenesis by downregulating significant angiogenic genes such as versican (VCAN), the growth factor receptor-binding protein 2 (Grb2), and enhancer of zeste homolog 2 (EZH2), which participates in histone methylation [99]. An in vivo study has confirmed that TQ reduced oxidative stress, prevented necrosis, enhanced regeneration, and downregulated the expression of miR-206b-3p in the liver tissue of mice with Ehrlich acid solid tumor after intraperitoneal injection with $10 \mathrm{mg} / \mathrm{kg}$ TQ for 4 weeks (five doses/week) [100]. In another in vivo study by Helmy et al. (2019), treated rats group received TQ $(20 \mathrm{mg} / \mathrm{Kg}$ body weight suspended in $0.5 \%$ carboxymethyl cellulose), daily by oral gavage tube along with Thioacetamide intraperitoneally injected for 16 weeks. The results revealed that TQ induced apoptosis by upregulating TNF-related apoptosis-inducing ligand (TRAIL) and caspase-3, and downregulating $\mathrm{Bcl} 2$ and transforming growth factor-beta 1 (TGF- $\beta 1$ ). Moreover, TQ improved liver function as well as reduced hepatocellular carcinoma progression [101].

Furthermore, TQ and TQ-NLC inhibited the growth, enhanced the cell cycle arrest, and increased the apoptosis rate of Hep3B at the same concentration. However, they have a different effect on ROS, while TQ acted as a prooxidant (increased ROS level), TQ-NLC performed as an antioxidant (reduced ROS level) [102]. A combination of $10 \mu \mathrm{M}$ TQ with $10,5,2.5$, and $1.25 \mu \mathrm{M}$ of DOX induced apoptosis in HepG2 and Huh7 cells by upregulating caspase- 3 and downregulating $\mathrm{Bcl} 2$ genes. The treatment also increased the miR-16 and miR-375 expression levels [103].

\subsection{Cervical Cancer}

Butt et al. (2019) reported that TQ induced distinct apoptotic pathways in SiHa and C33-A human cervical squamous cell carcinoma. The qPCR results exhibited that TQ increases apoptosis in SiHa cells by increasing the expression level of p53, whereas apoptosis in C33A cells was primarily related to the upregulation of caspase-3 [104]. In SiHa and CaSki cervical cancer cell lines, $10 \mu \mathrm{M}$ TQ has shown an ability to suppress the cancer metastasis, migration, and invasion by reducing Twist1 and Zeb1 expression and inducing E-cadherin expression in a dose- and time-dependent manner. The luciferase reporter assay also confirmed that TQ decreases the Twist1 and Zeb1 promoter activities, indicating that Twist1 and Zeb1 might be the TQ's direct targets [105]. TQ-loaded nanostructured lipid carrier $(1.56$ and $3.125 \mu \mathrm{M})$ reduced the proliferation of HeLa cell line in a time- and dose-dependent manner [106]. At high concentrations against HeLa cells, TQ has enhanced apoptosis by downregulating the anti-apoptotic genes, such as NF-kappa-B signaling, and mediating the expressions of BID, TNFRSF10B, TNF, TNFRSF10 A, RELA, TRAF3, and RELB, and upregulating caspase-1, BIK, and FASL [1].

\subsection{Leukemia}

A combination of $10 \mu \mathrm{M}$ TQ and $50 \mathrm{nM}$ DOX has enhanced apoptosis in aggressive adult T-cell leukemia (ATL) more than the treatment with TQ or DOX alone by increasing the ROS production in both Jurkat and HuT-102 cell lines. Additionally, Jurkat cells' treatment with the TQ and DOX combination has regulated the essential regulatory proteins [60]. TQ combination with arsenic/interferon-alpha (As/IFN- $\alpha$ ) has induced apoptosis in T-cell leukemia/lymphoma by upregulating Bax and p53, downregulating Bcl2, and activating caspase-3. TQ also disrupted the activity of the mitochondrial membrane. In xenograft mouse model, animals were injected intraperitoneally with a TQ/As/IFN- $\alpha$ combination. TQ (20 mg/kg body weight), As (2.5 $\mu \mathrm{g} / \mathrm{g} /$ day), and IFN- $\alpha$ (105 IU/day/mouse). At the end of the experiment, tumors were collected for immunoblotting analysis. In accordance with the in vitro results, PARP and caspase 3 were cleaved in tissues of mice injected with TQ/As/IFN- $\alpha$. Caspase 3 cleavage was also detected in the TQ group but was less than in the combination groups. Significant upregulation of Bax was seen in the triple combi- 
nation only [107]. A previous study by Musalli et al. (2019) on an HL-60 acute myeloid leukemia (AML) cell line showed that 5, 10 and $30 \mu \mathrm{M}$ TQ treatment significantly reduced cell viability, induced apoptosis of HL60, and downregulated the expression of WT1 and Bcl-2 genes in a dose- and time-dependent manner [108].

A study by Pang et al. (2017) showed that TQ (3, $10 \mu \mathrm{M})$ suppressed cancer growth in THP-1 and MV4-11 leukemia cell lines by reducing the activity of DNA-methyltransferase 1 (DNMT1), As such, it decreased the total DNA methylation in two ways; downregulating DNMT1 and competing with co-factor SAM/SAH to inactivate DNMT1. TQ also reduced colony formation and induced apoptosis via activation of caspases [9]. Furthermore, TQ modulated Wnt signaling through glycogen synthase kinase (GSK)-3b activation, b-catenin translocation and nuclear c-Myc reduction. TQ has been shown to mediate ROS damage in adult $\mathrm{T}$ cell leukemia [7].

\subsection{Head and Neck Cancer}

A combination of $5 \mu \mathrm{M}$ TQ and $5 \mu \mathrm{M}$ ) cisplatin increased the apoptosis in head and neck squamous cell carcinoma cells (UMSCC-14C) by inducing the expression levels of p53 and caspase-9 proteins and inhibiting Bcl-2 [109]. TQ combined with radiation inhibited proliferation and induced apoptosis more than a TQ-cisplatin combination against SCC25 and CAL27 cell lines [110]. TQ (1 and $5 \mu \mathrm{M})$ inhibited the proliferation, migration and invasion and induced apoptosis in oral squamous cell carcinoma KB cell line by inhibiting the PI3K/Akt pathway activity [92].

\section{Epigenetic Role of TQ}

The significant epigenetic changes consist of acetylation/deacetylation, DNA methylation/demethylation, RNA interferences, and nucleosome remodeling. Epigenetic changes are critical in regulating gene expression and protein activity [111]. The perturbation of epigenetic systems causes abnormal silencing or activation of genes and proteins, and leads to diseases, including cancers [112]. For this purpose, it is crucial to prevent epigenetic modifications without affecting the normal cells.

\subsection{Histone Acetylation/Deacetylation}

TQ has inhibited the histone deacetylase (HDAC) enzyme and reduced its total activity. As a result, TQ reactivated the HDAC target genes such as p21 and Maspin and proapoptotic gene Bax while downregulating the antiapoptotic gene $\mathrm{Bcl}-2$ and increasing the percentage of cell cycle arrest at the G2/M phase [113]. A study by Relles et al. (2016) has reported that the treatment of AsPC-1 and MiaPaCa-2 pancreatic ductal adenocarcinoma cell lines with TQ induced the acetylation of H4 (lysine 12) and reduced HDACs activity, as well as decreasing the expression of HDAC1, HDAC2, and HDAC3 by 40-60\% [114].

In non-cancer cells, TQ can increase cellular NAD+ [115]. NAD+ is a regulator of sirtuin 1 (SIRT1), which could potentially deacetylate proteins $[116,117]$. An increase in the levels of intracellular NAD+ led to the activation of the SIRT1-dependent metabolic pathways [118]. SIRT1 played a crucial regulatory role in cardiovascular disease by activating FOXO to reduce the apoptotic molecules and oxidative stress for cardio protection [119]. Activating SIRT1 by TQ led to p53 acetylation inhibition and apoptosis reduction that resulted from myocardial ischemia/reperfusion (MI/R) injury in cardiomyocytes [120]. On the other hand, TQ induced apoptosis by downregulating SIRT1 and upregulating p73 in the T cell leukemia Jurkat cell line [121].

\subsection{DNA Methylation/Demethylation}

According to previous studies, TQ may act as a methylating and a demethylating agent targeting the DNA methyltransferase 1 (DNMT1) and decreasing the DNA methylation in CpG islands (Figure 3) [122]. A study by Pang et al. (2017) revealed that TQ enhanced the Sp1-NF- $\kappa$ B complex separation from the DNMT1 promoter, leading to DNMT1 inhibition. As a result of the induced apoptosis by caspase and reduced colony formation [9], TQ 
could stop epigenetic alterations in human breast carcinoma MCF-7 resistance against doxorubicin MCF-7/DOX cells through the re-expression of tumor suppressor gene PTEN and activation of caspase [60]. Many transcription factors had a main role in cancer metastasis, such as Zeb1, Twist1, Slug, and Snail1 [105]. TQ induced the methylation of the Twist1 promoter in the breast cancer cell line, which led to the downregulation of Twist1 [8]. Similarly, Twist1 and Zeb1 were downregulated by increasing promoter methylation in cervical cancer CaSki and SiHa cell lines [105].

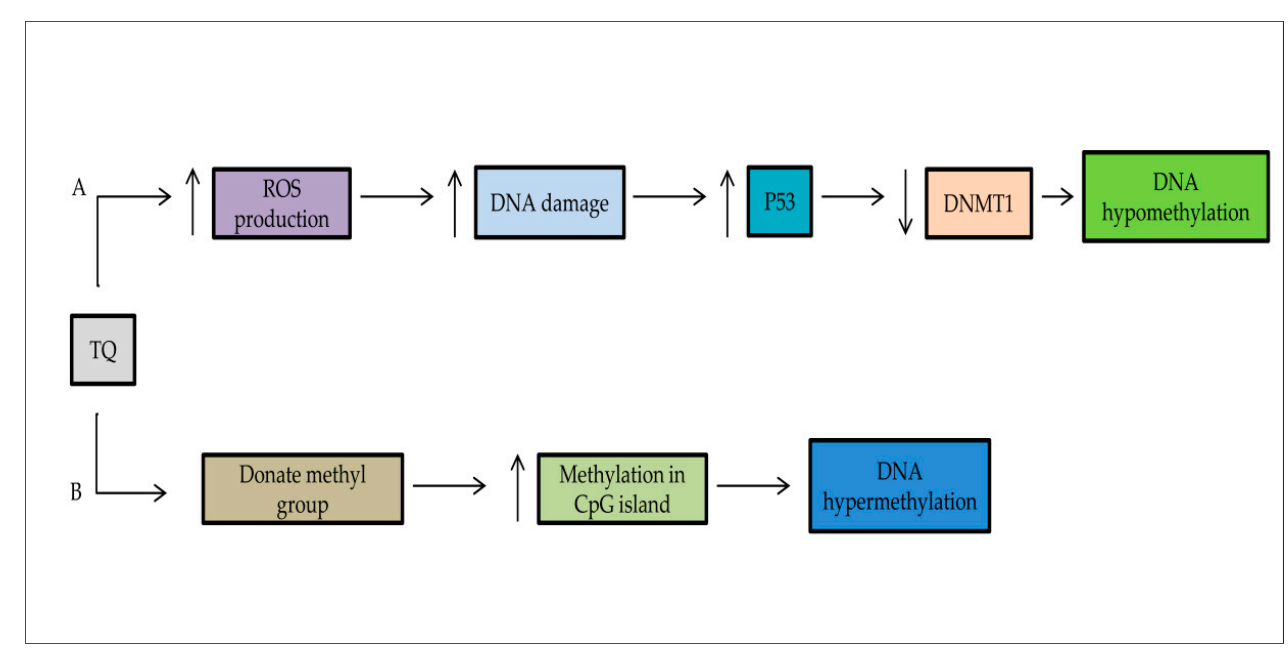

Figure 3. The double action of TQ on DNA methylation. (A) TQ has the potential to repair the epigenetic aberrations in cancer cells and upregulation of tumor suppressor genes such as p53, p73. It leads to the downregulation of DNA methyltransferase DNMT1. (B) TQ can methylate the CpG islands of genomic DNA.

\subsection{Activating and Deactivating Noncoding RNAs}

$\mathrm{TQ}$ is potent enough to regulate miRNA expression $[62,103]$. Activating the miR34a to inhibit the epithelial-mesenchymal transition transcription factors (EMT-TFs) is a promising therapeutic approach against breast cancer metastasis [123]. Imani et al. (2017) reported that TQ enhanced the miR34a to directly target Twist1 and Zeb1 in the triple-negative breast cancer cell line BT549. Consequently, it inhibited EMT signaling pathways [76]. TQ also reduced the expression of miR-206b-3p, which is related to the increased oxidative stress in the liver tissue of mice with Ehrlich acid solid tumors [100]. Moreover, TQ's use with nanoparticles leads to the expression of miR34a, which may lead to an anti-migratory effect in breast cancer [33].

\section{Antioxidant and Anti-Inflammatory Activities of TQ}

Oxidative stress and inflammation could lead to cancer [124]. Hossen et al. (2017) analyzed the anti-inflammatory effect of TQ and its targeted proteins. They reported that TQ inhibited LPS-, pam3CSK-, and Poly (I:C)-mediated NO generation in a dose-dependent manner in macrophage RAW264.7 cells and primary peritoneal macrophages. The same study showed that TQ completely reduced LPS-triggered PGE2 at $25 \mu \mathrm{M}$. Moreover, by oral administration, TQ had the same effect as ranitidine, which is considered an anti-ulcer activity drug, both decreasing gastritis by up to $98 \%$ [125]. TQ treatment of male SpragueDawley rats has reduced the inflammatory markers (CRP, TNF- $\alpha$, IL-6, and IL-1 $\beta$ ) and anti-inflammatory cytokines (IL-10 and IL-4) triggered by sodium nitrite [126].

Furthermore, TQ has shown a dose-dependent anti-inflammatory effect on carrageenaninduced rat hind paw edema and cottonseed pellet granuloma compared with the reference drug indomethacin [127]. TQ-piperin combination has reduced the inflammation resulting from microcystin in mice, lowering inflammatory markers (IL-1 $\beta$, IL-6 and TNF- $\alpha$ ) in the serum. The TQ-piperin combination has also decreased the oxidative damage triggered by 
microcystin in liver tissue and reduced malondialdehyde (MDA) and NO, while inducing glutathione (GSH) levels and superoxide dismutase (SOD), catalase (CAT), and glutathione peroxidase (GSH-Px) activities [128]. Furthermore, TQ could reduce LPS-mediated inflammatory cytokine secretion, monocyte recruitment factors, and monocyte in human endothelial (HECV) cell lines. It could also downregulate the gene expression of VEGF and monocyte chemotactic protein-1 [129].

\section{Tyrosine Kinase Inhibitors as a Candidate Anti-Cancer Agent Combined with TQ}

Overexpression of the protein tyrosine kinase (PTK) gene has increased the activity of PTK and modulated its downstream signaling pathways, promoting cell proliferation disorders and ultimately leading to tumor formation [130]. Clinical studies revealed that PTK overexpression or decreased expression can exhibit the tumor's biological features or predict treatment and survival [131]. Tyrosine kinase inhibitors (TKI) can compete with ATP for the ATP binding site of PTK and reduce tyrosine kinase phosphorylation [132]. These drugs have valuable properties, such as high selectivity, high efficacy, low side effects, ease of preparation, and an advantage in the treatment of chronic myeloid leukemia (CML), nonsmall cell lung cancer (NSCLC), and renal cell carcinoma (RCC) than common cytotoxic antineoplastic agents [133]. The anti-tumor mechanism of Tyrosine kinase inhibitors (TKI) can be performed by inhibiting tumor cells' growth, anti-angiogenesis, blocking the cell division in the G1 phase, and inducing apoptosis [134]. Most cancer patients are relieved after using TKI but the acquired resistance remains the principal obstacle in cancer therapy [135]. TKI has a variety of mechanisms for drug resistance. One of the most common is the loss of PTEN expression because of hypermethylation [131]. PTEN has been considered a tumor suppressor gene that is closely related to reducing tumorigenesis and progression [136]. In a study on the lung adenocarcinoma HCC827 cell line, Ni et al. (2017) showed that efatutazone, which acted as an upregulator for PPAR and PTEN and inactivator for Akt pathway, improved the action of TKI and could have therapeutic effects in cancer [137].

Several studies had proven TQ's potential to activate tumor suppressor genes by a demethylating process for many methylated genes in cancer cells (Figure 4); PTEN is among these genes, as mentioned above. TQ treatment has upregulated PTEN expression, resulting in a substantial inhibition of phosphorylated Akt, a known regulator of cell survival. The PTEN expression was accompanied by an elevation of PTEN protein [10,137].

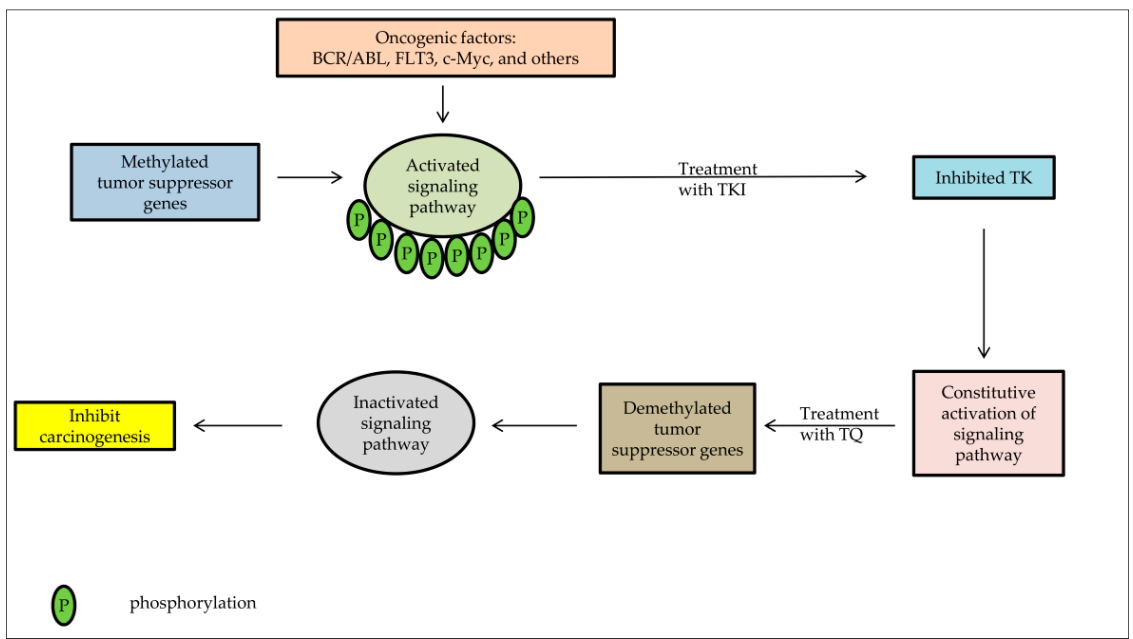

Figure 4. The effect of TKI and TQ treatment combination on cancer cells. In the absence of TSGnegative regulation due to hypermethylation, there will be constitutive activation of signaling pathways even though TKI has inhibited TK, resulting in resistance to TKI. However, after treatment with TQ, there will be reactivation of Tumor suppressor genes (TSG) resulting in inhibition of signaling pathways leading to suppression of cancer cell proliferation. 


\section{Conclusions}

TQ is the main bioactive constituent in N. sativa that has been intensively investigated in vitro and in vivo and shown to have several therapeutic properties, including anticancer activity. Its effectiveness on cancers is demonstrated in murine model studies in which TQ enhances higher survival rates, reduced tumor volume, reduced pro-cancerous molecules and elevated anti-tumorigenesis biomarkers. Meanwhile, in in vitro studies, TQ has shown the ability to inhibit cancer staging such as migration, proliferation, and invasion or apoptosis induction by repressing the activation of vital pathways, such as JAK/STAT and PI3K/AKT/mTOR. However, the TQ effect mechanism on cancers is still not fully understood. It is important to note that the discovery of selective anticancer agents such as tyrosine kinase inhibitors (TKI) represents a revolution in cancer treatment. However, the resistance to such therapeutic agents is one of the main challenges in cancer treatment, and different mechanisms to develop such resistance have been postulated. Activation of signaling pathways and epigenetic methylation of tumor suppressor genes (TSG) plays a crucial role in acquiring resistance to TKI. Re-expression of TSG by using demethylating agents represents a critical approach in cancer treatment. Based on the present review, it is recommended that more intensive studies of TQ's effects, alone or in combination with TKI, on the expression of TSG and different signaling pathways that represent critical strategy in cancer treatment, are conducted. It is also recommended that nanoparticle technology and analogs be used to improve TQ drug effectiveness.

Author Contributions: Conceptualization, H.A.N.A.-J. and B.A.; literature Search, B.A.; writingoriginal draft preparation, B.A.; writing-review and editing, H.A.N.A.-J., A.A.D., W.R.W.T., I.I., M.F.J., W.N.I.; supervision, H.A.N.A.-J. All authors have read and agreed to the published version of the manuscript.

Funding: This work was funded by the Fundamental Research Grant Scheme of the Ministry of Education, Malaysia [FRGS/1/2019/SKK08/UNISZA/02/3 (RR330)].

Institutional Review Board Statement: Not applicable.

Informed Consent Statement: Not applicable.

Data Availability Statement: Not applicable.

Conflicts of Interest: The authors declare no conflict of interest.

$\begin{array}{ll}\text { Abbreviations } & \\ \text { AGP } & \text { 11-acid glycoprotein } \\ \text { BPH } & \text { Benign prostatic hyperplasia } \\ \text { BSA } & \text { Bovine serum albumin } \\ \text { CAT } & \text { Catalase } \\ \text { CD } & \text { Cyclodextrin } \\ \text { COX2 } & \text { Cyclooxygenase-2 } \\ \text { CS } & \text { Chitosan } \\ \text { CXCR4 } & \text { Chemokine receptor Type } 4 \\ \text { DNMT1 } & \text { DNA-methyltransferase 1 } \\ \text { DOX } & \text { Doxorubicin } \\ \text { eEF-2K } & \text { Eukaryotic elongation Factor } 2 \text { kinase } \\ \text { EMT } & \text { Epithelial-mesenchymal transition } \\ \text { EZH2 } & \text { Enhancer of zeste homolog } 2 \\ \text { GK } & \text { Gamma Knife } \\ \text { Grb2 } & \text { Growth factor receptor-binding protein } 2 \\ \text { GSH } & \text { Glutathione } \\ \text { GSH-Px } & \text { Glutathione peroxidase } \\ \text { GSK } & \text { Glycogen synthase kinase } \\ \text { HDAC } & \text { Histone deacetylase }\end{array}$




$\begin{array}{ll}\text { HSA } & \text { Human serum albumin } \\ \text { IC50 } & \text { 50\% inhibitory concentration } \\ \text { IFN } & \text { Interferon } \\ \text { IL } & \text { Interleukin } \\ \text { I3M } & \text { Indirubin-3-monoxime } \\ \text { JAK } & \text { Janus kinase } \\ \text { JNK } & \text { c-Jun N-terminal kinase pathway } \\ \text { LD50 } & \text { Median lethal dose } \\ \text { LNPs } & \text { Lipid-based nanoparticles } \\ \text { LPA } & \text { Lysophosphatidic acid } \\ \text { MA } & \text { Myristic acid } \\ \text { MAPK } & \text { Mitogen-activated protein kinase } \\ \text { MDA } & \text { malondialdehyde } \\ \text { MMP9 } & \text { Matrix metallopeptidase } 9 \\ \text { MOMP } & \text { Mitochondrial outer membrane permeability } \\ \text { mTOR } & \text { Mammalian target of rapamycin } \\ \text { NF-Kb } & \text { Nuclear factor kappa B } \\ \text { NK } & \text { Natural killer } \\ \text { NLCs } & \text { Nanostructured lipid carriers } \\ \text { PBS } & \text { Phosphate-buffered saline } \\ \text { PCL } & \text { Poly- }- \text {-caprolactone } \\ \text { PEG } & \text { Polyethylene glycol } \\ \text { P-gP } & \text { P-glycoprotein } \\ \text { PI3K } & \text { Phosphoinositide 3-kinases } \\ \text { PLGA } & \text { Poly-lactide-co-glycolide } \\ \text { PPAR } \gamma & \text { Peroxisome proliferator-activated receptor- } \gamma \\ \text { PTEN } & \text { Phosphatase and tensin homolog } \\ \text { PTK } & \text { Protein tyrosine kinase } \\ \text { PTX } & \text { Paclitaxel } \\ \text { ROS } & \text { Reactive oxygen species } \\ \text { SLNs } & \text { Solid lipid nanocarriers } \\ \text { SOD } & \text { Superoxide dismutase } \\ \text { STAT } & \text { Signal transducer and activator of transcription } \\ \text { TF } & \text { Transferrin } \\ \text { TGF- } \beta 1 & \text { Transforming growth factor-beta 1 } \\ \text { TKI } & \text { Tyrosine kinase inhibitors } \\ \text { TME } & \text { Tumor microenvironment } \\ \text { TNBC } & \text { Triple-negative breast cancer } \\ \text { TQ } & \text { Thymoquinone } \\ \text { TRAIL } & \text { TNF-related apoptosis-inducing ligand } \\ \text { TSG } & \text { Tumor suppressor genes } \\ \text { VCAN } & \text { Versican } \\ \text { VEGFR } & \text { Vascular endothelial growth factor Receptor } \\ & \end{array}$

\section{References}

1. Imran, M.; Rauf, A.; Khan, I.A.; Shahbaz, M.; Qaisrani, T.B.; Fatmawati, S.; Abu-Izneid, T.; Imran, A.; Rahman, K.U.; Gondal, T.A. Thymoquinone: A novel strategy to combat cancer: A review. Biomed. Pharmacother. 2018, 106, 390-402. [CrossRef] [PubMed]

2. Ahmad, N.; Ahmad, R.; Al-Layly, A.; Al-Shawi, H.; Al-Ali, A.; Amir, M.; Mostafa, A. Ultra-high-performance liquid chromatography-based identification and quantification of thymoquinone in Nigella sativa extract from different geographical re-gions. Pharmacogn. Mag. 2018, 14, 471. [CrossRef]

3. Awad, A.S.M.; Al Haleem, E.N.A.; El-Bakly, W.M.; Sherief, M.A. Thymoquinone alleviates nonalcoholic fatty liver disease in rats via suppression of oxidative stress, inflammation, apoptosis. Naunyn-Schmiedeberg's Arch. Pharmacol. 2016, 389, 381-391. [CrossRef]

4. Ebrahimi, S.S.; Oryan, S.; Izadpanah, E.; Hassanzadeh, K. Thymoquinone exerts neuroprotective effect in animal model of Parkinson's disease. Toxicol. Lett. 2017, 276, 108-114. [CrossRef]

5. Abulfadl, Y.S.; El-Maraghy, N.N.; Ahmed, A.E.; Nofal, S.; Abdel-Mottaleb, Y.; Badary, A.O. Thymoquinone alleviates the experimentally induced Alzheimer's disease inflammation by modulation of TLRs signaling. Hum. Exp. Toxicol. 2018, 37, 1092-1104. [CrossRef] [PubMed] 
6. Ecevit, H.; Gunduz, K.; Bilgic, N.; Izmirli, M.; Gogebakan, B. The effect of thymoquinone on BEAS-2B cell viability and TGF- $\beta 1$ release. AMOR 2017, 3, 15-19. [CrossRef]

7. Khan, A.; Tania, M.; Fu, S.; Fu, J. Thymoquinone, as an anticancer molecule: From basic research to clinical investigation. Oncotarget 2017, 8, 51907-51919. [CrossRef] [PubMed]

8. Khan, M.D.; Tania, M.; Wei, C.; Mei, Z.; Fu, S.; Cheng, J.; Xu, J.; Fu, J. Thymoquinone inhibits cancer metastasis by downreg-ulating TWIST1 expression to reduce epithelial to mesenchymal transition. Oncotarget 2015, 6, 19580. [CrossRef] [PubMed]

9. $\quad$ Pang, J.; Shen, N.; Yan, F.; Zhao, N.; Dou, L.; Wu, L.-C.; Seiler, C.L.; Yu, L.; Yang, K.; Bachanova, V.; et al. Thymoquinone exerts potent growth-suppressive activity on leukemia through DNA hypermethylation reversal in leukemia cells. Oncotarget 2017, 8, 34453-34467. [CrossRef] [PubMed]

10. Barkat, M.D.; Ahmad, J.; Khan, M.A.; Beg, S.; Ahmad, F.J. Insights into the targeting potential of thymoquinone for therapeu-tic intervention against triple-negative breast cancer. Curr. Drug Targets 2018, 19, 70-80. [CrossRef] [PubMed]

11. Samarghandian, S.; Azimi-Nezhad, M.; Farkhondeh, T. Thymoquinone-induced antitumor and apoptosis in human lung adenocarcinoma cells. J. Cell. Physiol. 2019, 234, 10421-10431. [CrossRef] [PubMed]

12. Martinovich, G.G.; Martinovich, I.V.; Vcherashniaya, A.V.; Shadyro, O.I.; Cherenkevich, S.N. Thymoquinone, a biologically active component of Nigella sativa, induces mitochondrial production of reactive oxygen species and programmed death of tumor cells. Biophys. 2016, 61, 963-970. [CrossRef]

13. Hsu, H.-H.; Chen, M.-C.; Day, C.H.; Lin, Y.-M.; Li, S.-Y.; Tu, C.-C.; Padma, V.V.; Shih, H.-N.; Kuo, W.-W.; Huang, C.-Y. Thymoquinone suppresses migration of LoVo human colon cancer cells by reducing prostaglandin E2 induced COX-2 activa-tion. World J. Gastroenterol. 2017, 23, 1171. [CrossRef] [PubMed]

14. Taha, E.M.M.; Sheikh, B.Y.; Salim, A.L.Z.; Mohan, S.; Khan, A.; Kamalidehghan, B.; Ahmadipour, F.; I Abdelwahab, S. Thymoquinone induces apoptosis and increase ROS in ovarian cancer cell line. Cell. Mol. Boil. 2016, 62, 97-101.

15. Sarman, H.; Bayram, R.; Benek, S.B. Anticancer drugs with chemotherapeutic interactions with thymoquinone in osteosar-coma cells. Eur. Rev. Med. Pharmacol. Sci. 2016, 20, 1263-1270.

16. Ahmad, A.; Mishra, R.K.; Vyawahare, A.; Kumar, A.; Rehman, M.U.; Qamar, W.; Khan, A.Q.; Khan, R. Thymoquinone (2Isopropyl-5-methyl-1, 4-benzoquinone) as a chemopreventive/anticancer agent: Chemistry and biological effects. Saudi Pharm. J. 2019, 27, 1113-1126. [CrossRef]

17. Zhu, W.-Q.; Wang, J.; Guo, X.-F.; Liu, Z.; Dong, W.-G. Thymoquinone inhibits proliferation in gastric cancer via the STAT3 pathway in vivo and in vitro. World J. Gastroenterol. 2016, 22, 4149. [CrossRef] [PubMed]

18. Upadhyay, P.; Sarker, S.; Ghosh, A.; Gupta, P.; Das, S.; Ahir, M.; Bhattacharya, S.; Chattopadhyay, S.; Ghosh, S.; Adhikary, A. Transferrin-decorated thymoquinone-loaded PEG-PLGA nanoparticles exhibit anticarcinogenic effect in non-small cell lung carcinoma via the modulation of miR-34a and miR-16. Biomater. Sci. 2019, 7, 4325-4344. [CrossRef] [PubMed]

19. Ali, B.H.; Blunden, G. Pharmacological and toxicological properties of Nigella sativa. Phytother. Res. 2003, 17, 299-305. [CrossRef]

20. Salem, M.L. Immunomodulatory and therapeutic properties of the Nigella sativa L. seed. Int. Immunopharmacol. 2005, 5, 1749-1770. [CrossRef]

21. Salmani, J.M.; Asghar, S.; Lv, H.; Zhou, J. Aqueous solubility and degradation kinetics of the phytochemical anticancer thymoquinone; probing the effects of solvents, $\mathrm{pH}$ and light. Molecules 2014, 19, 5925-5939. [CrossRef] [PubMed]

22. Darakhshan, S.; Pour, A.B.; Colagar, A.H.; Sisakhtnezhad, S. Thymoquinone and its therapeutic potentials. Pharmacol. Res. 2015, 95-96, 138-158. [CrossRef]

23. Nagi, M.N.; Almakki, H.A. Thymoquinone supplementation induces quinone reductase and glutathione transferase in mice liver: Possible role in protection against chemical carcinogenesis and toxicity. Phytotherapy Res. 2009, 23, 1295-1298. [CrossRef] [PubMed]

24. Rahmani, A.H.; Alzohairy, M.A.; Khan, M.A.; Aly, S.M. Therapeutic implications of black seed and its constituent thymo-quinone in the prevention of cancer through inactivation and activation of molecular pathways. Evid. Based Complement Alternat. Med. 2014, 2014. [CrossRef] [PubMed]

25. Mansour, M.A.; Ginawi, O.T.; El-Hadiyah, T.; El-Khatib, A.S.; Al-Shabanah, O.A.; Al-Sawaf, H.A. Effects of volatile oil con-stituents of Nigella sativa on carbon tetrachloride-induced hepatotoxicity in mice: Evidence for antioxidant effects of thymo-quinone. Res. Commun. Mol. Pathol. Pharmacol. 2001, 110, 239-252.

26. Kanter, M. Thymoquinone attenuates lung injury induced by chronic toluene exposure in rats. Toxicol. Ind. Heal. 2010, 27, 387-395. [CrossRef]

27. Jain, A.; Pooladanda, V.; Bulbake, U.; Doppalapudi, S.; Rafeeqi, T.A.; Godugu, C.; Khan, W. Liposphere mediated topical delivery of thymoquinone in the treatment of psoriasis. Nanomed. Nanotechnol. Biol. Med. 2017, 13, 2251-2262. [CrossRef]

28. Lupidi, G.; Scire, A.; Camaioni, E.; Khalife, K.H.; De Sanctis, G.; Tanfani, F.; Damiani, E. Thymoquinone, a potential thera-peutic agent of Nigella sativa, binds to site I of human serum albumin. Phytomedicine 2010, 17, 714-720. [CrossRef]

29. El-Najjar, N.; Ketola, R.A.; Nissilä, T.; Mauriala, T.; Antopolsky, M.; Jänis, J.; Gali-Muhtasib, H.; Urtti, A.; Vuorela, H. Impact of protein binding on the analytical detectability and anticancer activity of thymoquinone. J. Chem. Biol. 2011, 4, 97-107. [CrossRef]

30. Zaher, N.H.; Rashed, E.R.; El-Ghazaly, M.A. Semi-synthetic thymoquinone analogs: New prototypes as potential antihyperlipidemics in irradiated rats. Future Med. Chem. 2017, 9, 1483-1493. [CrossRef]

31. Johnson-Ajinwo, O.R.; Ullah, I.; Mbye, H.; Richardson, A.; Horrocks, P.; Li, W.-W. The synthesis and evaluation of thymo-quinone analogues as anti-ovarian cancer and antimalarial agents. Bioorg. Med. Chem. Lett. 2018, 28, 1219-1222. [CrossRef] [PubMed] 
32. Glamočlija, U.; Padhye, S.; Špirtović-Halilović, S.; Osmanović, A.; Veljović, E.; Roca, S.; Novakovic, I.; Mandic, B.; Turel, I.; Kljun, J.; et al. Synthesis, biological evaluation and docking studies of benzoxazoles derived from thymoquinone. Molecules 2018, 23, 3297. [CrossRef] [PubMed]

33. Bhattacharya, S.; Ahir, M.; Patra, P.; Mukherjee, S.; Ghosh, S.; Mazumdar, M.; Chattopadhyay, S.; Das, T.; Chattopadhyay, D.; Adhikary, A. PEGylated-thymoquinone-nanoparticle mediated retardation of breast cancer cell migration by deregulation of cytoskeletal actin polymerization through miR-34a. Biomaterials 2015, 51, 91-107. [CrossRef]

34. Kumari, S.; Mg, S.; Mayor, S. Endocytosis unplugged: Multiple ways to enter the cell. Cell Res. 2010, 20, 256-275. [CrossRef]

35. Dinarvand, R.; Sepehri, N.; Manouchehri; Rouhani, H.; Atyabi, F. Polylactide-co-glycolide nanoparticles for controlled delivery of anticancer agents. Int. J. Nanomed. 2011, 6, 877-895. [CrossRef] [PubMed]

36. Ballout, F.; Habli, Z.; Rahal, O.N.; Fatfat, M.; Gali-Muhtasib, H. Thymoquinone-based nanotechnology for cancer therapy: Promises and challenges. Drug Discov. Today 2018, 23, 1089-1098. [CrossRef]

37. Ganea, G.M.; Fakayode, S.O.; Losso, J.N.; Van Nostrum, C.F.; Sabliov, C.M.; Warner, I.M. Delivery of phytochemical thy-moquinone using molecular micelle modified poly (D, L lactide-co-glycolide)(PLGA) nanoparticles. Nanotechnology 2010, 21, 285104. [CrossRef]

38. Sun, H.; Guo, B.; Cheng, R.; Meng, F.; Liu, H.; Zhong, Z. Biodegradable micelles with sheddable poly(ethylene glycol) shells for triggered intracellular release of doxorubicin. Biomaterials 2009, 30, 6358-6366. [CrossRef]

39. Shah, M.; Choi, M.H.; Ullah, N.; Kim, M.O.; Yoon, S.C. Synthesis and characterization of PHV-block-mPEG diblock copoly-mer and its formation of amphiphilic nanoparticles for drug delivery. J. Nanosci. Nanotechnol. 2011, 11, 5702-5710. [CrossRef]

40. Mona, M.A.; Mottaleb, A. Biodegradable thymoquinone nanoparticles for higher therapeutic efficiency in murine colorectal cancer. Int. J. Pharm. Pharm. Res. 2016, 7, 436-450.

41. Del Valle, E. Cyclodextrins and their uses: A review. Process. Biochem. 2004, 39, 1033-1046. [CrossRef]

42. Abu-Dahab, R.; Odeh, F.; Ismail, S.I.; Azzam, H.; Al Bawab, A. Preparation, characterization and antiproliferative activity of thymoquinone- $\beta$-cyclodextrin self-assembling nanoparticles. Pharmazie 2013, 68, 939-944. [PubMed]

43. Wang, T.; Luo, Y. Biological fate of ingested lipid-based nanoparticles: Current understanding and future directions. Nanoscale 2019, 11, 11048-11063. [CrossRef] [PubMed]

44. Akbarzadeh, A.; Rezaei-Sadabady, R.; Davaran, S.; Joo, S.W.; Zarghami, N.; Hanifehpour, Y.; Samiei, M.; Kouhi, M.; Nejati-Koshki, K. Liposome: Classification, preparation, and applications. Nanoscale Res. Lett. 2013, 8, 102. [CrossRef] [PubMed]

45. Gregoriadis, G. Engineering liposomes for drug delivery: Progress and problems. Trends Biotechnol. 1995, 13, 527-537. [CrossRef]

46. Odeh, F.; Ismail, S.I.; Abu-Dahab, R.; Mahmoud, I.S.; Al Bawab, A. Thymoquinone in liposomes: A study of loading efficiency and biological activity towards breast cancer. Drug Deliv. 2012, 19, 371-377. [CrossRef] [PubMed]

47. Durak, S.; Rad, M.E.; Yetisgin, A.A.; Sutova, H.E.; Kutlu, O.; Cetinel, S.; Zarrabi, A. Niosomal Drug Delivery Systems for Ocular Disease-Recent Advances and Future Prospects. Nanomaterials 2020, 10, 1191. [CrossRef] [PubMed]

48. Moghassemi, S.; Hadjizadeh, A. Nano-niosomes as nanoscale drug delivery systems: An illustrated review. J. Control. Release 2014, 185, 22-36. [CrossRef]

49. Rajput, S.; Puvvada, N.; Kumar, B.N.; Sarkar, S.; Konar, S.; Bharti, R.; Dey, G.; Mazumdar, A.; Pathak, A.; Fisher, P.B. Overcoming Akt induced therapeutic resistance in breast cancer through siRNA and thymoquinone encapsulated multila-mellar gold niosomes. Mol. Pharm. 2015, 12, 4214-4225. [CrossRef]

50. Üner, M. Characterization and Imaging of Solid Lipid Nanoparticles and Nanostructured Lipid Carriers. Handb. Nanoparticles 2016, 117-141. [CrossRef]

51. Singh, A.; Ahmad, I.; Akhter, S.; Jain, G.K.; Iqbal, Z.; Talegaonkar, S.; Ahmad, F.J. Nanocarrier based formulation of Thymoquinone improves oral delivery: Stability assessment, in vitro and in vivo studies. Colloids Surf. B 2013, 102, 822-832. [CrossRef] [PubMed]

52. Surekha, R.; Aishwarya, V.; Sumathi, T. Thymoquinone loaded solid lipid nanoparticle: Formulation, characterization and in-vitro cell viability assay. Int. J. Pharm. Bio. Sci. 2014, 6, 449-464.

53. Badawy, M.E.; Rabea, E.I. A biopolymer chitosan and its derivatives as promising antimicrobial agents against plant patho-gens and their applications in crop protection. Int. J. Carbohydr. Chem. 2011, 2011. [CrossRef]

54. Cheba, B.A. Chitin and chitosan: Marine biopolymers with unique properties and versatile applications. Glob. J. Biotechnol. Biochem. 2011, 6, 149-153.

55. Othman, N.; Masarudin, M.J.; Kuen, C.Y.; Dasuan, N.A.; Abdullah, L.C. Synthesis and optimization of chitosan nanoparti-cles loaded with L-ascorbic acid and thymoquinone. Nanomaterials 2018, 8, 920. [CrossRef] [PubMed]

56. Alam, S.; Khan, Z.I.; Mustafa, G.; Kumar, M.; Islam, F.; Bhatnagar, A.; Ahmad, F.J. Development and evaluation of thymo-quinoneencapsulated chitosan nanoparticles for nose-to-brain targeting: A pharmacoscintigraphic study. Int. J. Nanomed. 2012 , 7, 5705. [CrossRef]

57. Talib, W.H. Regressions of Breast Carcinoma Syngraft Following Treatment with Piperine in Combination with Thymoquinone. Sci. Pharm. 2017, 85, 27. [CrossRef]

58. Dastjerdi, M.N.; Mehdiabady, E.M.; Iranpour, F.G.; Bahramian, H. Effect of thymoquinone on P53 gene expression and consequence apoptosis in breast cancer cell line. Int. J. Prev. Med. 2016, 7. [CrossRef]

59. Yıldırım, I.H.; Azzawri, A.A.; Duran, T. Thymoquinone induces apoptosis via targeting the Bax/BAD and Bcl-2 pathway in breast cancer cells. Dicle Tip Derg. 2019, 46, 411-417. [CrossRef] 
60. Fatfat, M.; Fakhoury, I.; Habli, Z.; Mismar, R.; Gali-Muhtasib, H. Thymoquinone enhances the anticancer activity of doxoru-bicin against adult T-cell leukemia in vitro and in vivo through ROS-dependent mechanisms. Life Sci. 2019, 232, 116628. [CrossRef]

61. Shanmugam, M.K.; Hsu, A.; Hui, K.M.; Tan, B.K.; Sethi, G. Abstract 4123: Thymoquinone inhibits bone metastasis in a breast cancer mouse model by modulating CXCR4/CXCL12 signaling axis. Tumor Biology 2016, 76, 4123. [CrossRef]

62. Bhattacharya, S.; Ghosh, A.; Maiti, S.; Ahir, M.; Debnath, G.H.; Gupta, P.; Bhattacharjee, M.; Ghosh, S.; Chattopadhyay, S.; Mukherjee, P. Delivery of thymoquinone through hyaluronic acid-decorated mixed Pluronic ${ }^{\circledR}$ nanoparticles to attenuate angiogenesis and metastasis of triple-negative breast cancer. J. Control. Release 2020, 322. [CrossRef] [PubMed]

63. Kabil, N.; Bayraktar, R.; Kahraman, N.; Mokhlis, H.A.; Calin, G.A.; Lopez-Berestein, G.; Ozpolat, B. Thymoquinone inhibits cell proliferation, migration, and invasion by regulating the elongation factor 2 kinase (eEF-2K) signaling axis in tri-ple-negative breast cancer. Breast Cancer Res. Treat. 2018, 171, 593-605. [CrossRef] [PubMed]

64. Şakalar, Ç.; İzgi, K.; İskender, B.; Sezen, S.; Aksu, H.; Çakır, M.; Kurt, B.; Turan, A.; Canatan, H. The combination of thy-moquinone and paclitaxel shows anti-tumor activity through the interplay with apoptosis network in triple-negative breast cancer. Tumor Biol. 2016, 37, 4467-4477. [CrossRef]

65. Chang, Y.; Yan, W.; Sun, C.; Liu, Q.; Wang, J.; Wang, M. miR-145-5p inhibits epithelial-mesenchymal transition via the JNK signaling pathway by targeting MAP3K1 in non-small cell lung cancer cells. Oncol. Lett. 2017, 14, 6923-6928. [CrossRef] [PubMed]

66. Yang, J.; Kuang, X.-R.; Lv, P.-T.; Yan, X.-X. Thymoquinone inhibits proliferation and invasion of human nonsmall-cell lung cancer cells via ERK pathway. Tumor Biol. 2014, 36, 259-269. [CrossRef]

67. Alhakamy, N.A.; Badr-Eldin, S.M.; A Fahmy, U.; Alruwaili, N.K.; Awan, Z.A.; Caruso, G.; Alfaleh, M.A.; Alaofi, A.L.; Arif, F.O.; Ahmed, A.A. Thymoquinone-Loaded Soy-Phospholipid-Based Phytosomes Exhibit Anticancer Potential against Human Lung Cancer Cells. Pharmaceutics 2020, 12, 761. [CrossRef]

68. Hussein, S.A.; Abdel-Aal, S.A.; Amin, A.; Khalaf, H.A. Caspase-3, Bcl-2, p53, CYP1A1 and COX-2 as a potential target in chemoprevention of Benzo (a) pyrene-induced lung carcinogenesis in mice: Role of thymoquinone. Nat. Sci. 2016, 4, $430-441$.

69. Dera, A.A.; Rajagopalan, P.; Al Fayi, M.; Ahmed, I.; Chandramoorthy, H.C. Indirubin-3-monoxime and thymoquinone ex-hibit synergistic efficacy as therapeutic combination in in-vitro and in-vivo models of Lung cancer. Arch. Pharm. Res. 2020, 43, 655-665. [CrossRef]

70. Singh, S.K.; Mishra, M.K.; Lillard, J.W.; Singh, R. Thymoquinone enhanced the tumoricidal activity of NK Cells against Lung Cancer. Am. Assoc. Immnol. 2018, 200, 124.5.

71. Wilson, A.J.; Saskowski, J.; Barham, W.; Yull, F.; Khabele, D. Thymoquinone enhances cisplatin-response through direct tu-mor effects in a syngeneic mouse model of ovarian cancer. J. Ovarian Res. 2015, 8, 46. [CrossRef]

72. Pazhouhi, M.; Sariri, R.; Rabzia, A.; Khazaei, M. Thymoquinone synergistically potentiates temozolomide cytotoxicity through the inhibition of autophagy in U87MG cell line. Iran. J. Basic. Med. Sci. 2016, 19, 890-898.

73. Bitarafan, S.; Yari, M.; Broumand, M.A.; Ghaderian, S.M.H.; Rahimi, M.; Mirfakhraie, R.; Azizi, F.; Omrani, M.D. Association of Increased Levels of lncRNA H19 in PBMCs with Risk of Coronary Artery Disease. Cell J. 2018, 20, 564-568.

74. Khalife, R.; Hodroj, M.H.; Fakhoury, R.; Rizk, S. Thymoquinone from Nigella sativa Seeds Promotes the Antitumor Activity of Noncytotoxic Doses of Topotecan in Human Colorectal Cancer Cells in Vitro. Planta Med. 2016, 82, 312-321. [CrossRef]

75. Dirican, A.; Atmaca, H.; Bozkurt, E.; Erten, C.; Karaca, B.; Uslu, R. Novel combination of docetaxel and thymoquinone in-duces synergistic cytotoxicity and apoptosis in DU-145 human prostate cancer cells by modulating PI3K-AKT pathway. Clin. Transl. Oncol. 2015, 17, 145-151. [CrossRef] [PubMed]

76. Imani, S.; Wei, C.; Cheng, J.; Khan, A.; Fu, S.; Yang, L.; Tania, M.; Zhang, X.; Xiao, X.; Zhang, X.; et al. MicroRNA-34a targets epithelial to mesenchymal transition-inducing transcription factors (EMT-TFs) and inhibits breast cancer cell migration and invasion. Oncotarget 2017, 8, 21362-21379. [CrossRef]

77. Feng, L.-M.; Wang, X.-F.; Huang, Q.-X. Thymoquinone induces cytotoxicity and reprogramming of EMT in gastric cancer cells by targeting PI3K/Akt/mTOR pathway. J. Biosci. 2017, 42, 547-554. [CrossRef] [PubMed]

78. Ma, J.; Hu, X.; Li, J.; Wu, D.; Lan, Q.; Wang, Q.; Tian, S.; Dong, W. Enhancing conventional chemotherapy drug cispla-tin-induced anti-tumor effects on human gastric cancer cells both in vitro and in vivo by thymoquinone targeting PTEN gene. Oncotarget 2017, 8, 85926. [CrossRef] [PubMed]

79. Chen, M.-C.; Lee, N.-H.; Hsu, H.-H.; Ho, T.-J.; Tu, C.-C.; Hsieh, D.J.-Y.; Lin, Y.-M.; Chen, L.-M.; Kuo, W.-W.; Huang, C.-Y. Thymoquinone Induces Caspase-Independent, Autophagic Cell Death in CPT-11-Resistant LoVo Colon Cancer via Mitochondrial Dysfunction and Activation of JNK and p38. J. Agric. Food Chem. 2015, 63, 1540-1546. [CrossRef] [PubMed]

80. Froehlich, T.; Ndreshkjana, B.; Muenzner, J.K.; Reiter, C.; Hofmeister, E.; Mederer, S.; Fatfat, M.; El-Baba, C.; Gali-Muhtasib, H.; Schneider-Stock, R. Synthesis of novel hybrids of thymoquinone and artemisinin with high activity and selec-tivity against colon cancer. ChemMedChem 2017, 12, 226-234. [CrossRef]

81. Chen, M.-C.; Lee, N.-H.; Hsu, H.; Ho, T.-J.; Tu, C.; Chen, R.-J.; Lin, Y.; Viswanadha, V.P.; Kuo, W.-W.; Huang, C.-Y. Inhibition of NF- $\mathrm{BB}$ and metastasis in irinotecan (CPT-11)-resistant LoVo colon cancer cells by thymoquinone via JNK and p38. Environ. Toxicol. 2016, 32, 669-678. [CrossRef] [PubMed]

82. Zhang, L.; Bai, Y.; Yang, Y. Thymoquinone chemosensitizes colon cancer cells through inhibition of NF-кB. Oncol. Lett. 2016, 12, $2840-2845$. [CrossRef]

83. Mohamed, A.M.; Refaat, B.A.; El-Shemi, A.G.; Kensara, O.A.; Ahmad, J.; Idris, S. Thymoquinone potentiates chemoprotec-tive effect of Vitamin D3 against colon cancer: A pre-clinical finding. Am. J. Transl. Res. 2017, 9, 774. [PubMed] 
84. Siegel, R.L.; Miller, K.D.; Jemal, A. Cancer statistics, 2016. CA A Cancer J. Clin. 2016, 66, 7-30. [CrossRef]

85. Kou, B.; Liu, W.; Zhao, W.; Duan, P.; Yang, Y.; Yi, Q.; Guo, F.; Li, J.; Zhou, J.; Kou, Q. Thymoquinone inhibits epitheli-almesenchymal transition in prostate cancer cells by negatively regulating the TGF- $\beta / \mathrm{Smad} 2 / 3$ signaling pathway. Oncol. Rep. 2017, 38, 3592-3598. [PubMed]

86. Singh, S.K.; Lillard Jr, J.W.; Singh, R. Thymoquinone regulates cytochrome P450 genes involved in prostate cancer disparity. Cancer Epidemiol. Biomark. Prev. 2018. [CrossRef]

87. Singh, S.K.; Apata, T.; Gordetsky, J.B.; Singh, R. Docetaxel Combined with Thymoquinone Induces Apoptosis in Prostate Cancer Cells via Inhibition of the PI3K/AKT Signaling Pathway. Cancers 2019, 11, 1390. [CrossRef]

88. Al-Trad, B.; Al-Zoubi, M.; Qar, J.; Al-Batayneh, K.; Hussien, E.; Muhaidat, R.; Aljabali, A.; Alkhateeb, H.; Al Omari, G. In-hibitory effect of thymoquinone on testosterone-induced benign prostatic hyperplasia in Wistar rats. Phytother. Res. 2017, 31, 1910-1915. [CrossRef]

89. Ranjbari, A.; Heidarian, E.; Ghatreh-Samani, K. Effects of Thymoquinone on IL-6 Gene Expression and Some Cellular Signaling Pathways in Prostate Cancer PC3 Cells. Jundishapur J. Nat. Pharm. Prod. 2017, 12. [CrossRef]

90. Park, J.E.; Kim, D.-H.; Ha, E.; Choi, S.M.; Choi, J.-S.; Chun, K.-S.; Joo, S.H. Thymoquinone induces apoptosis of human epi-dermoid carcinoma A431 cells through ROS-mediated suppression of STAT3. Chem. Biol. Interact. 2019, 312, 108799. [CrossRef]

91. Jeong, H.; Yu, S.; Kim, S.J. Inhibitory effects on melanogenesis by thymoquinone are mediated through the $\beta$-catenin pathway in B16F10 mouse melanoma cells. Int. J. Oncol. 2019, 56, 379-389. [CrossRef] [PubMed]

92. Ren, X.; Luo, W. Exploration of pro-apoptotic effect of Thymoquinone on oral squamous cell carcinoma cells through PI3K/Akt signaling pathway. Cell. Mol. Biol. 2019, 65, 61-64. [CrossRef]

93. Hatiboglu, M.A.; Koçyiğit, A.; Guler, E.M.; Akdur, K.; Nalli, A.; Karatas, E.; Tüzgen, S. Thymoquinone Induces Apoptosis in B16-F10 Melanoma Cell Through Inhibition of p-STAT3 and Inhibits Tumor Growth in a Murine Intracerebral Melanoma Model. World Neurosurg. 2018, 114, e182-e190. [CrossRef]

94. Hatiboglu, M.A.; Kocyigit, A.; Guler, E.M.; Akdur, K.; Khan, I.; Nalli, A.; Karatas, E.; Tuzgen, S. Thymoquinone Enhances the Effect of Gamma Knife in B16-F10 Melanoma Through Inhibition of Phosphorylated STAT3. World Neurosurg. 2019, 128, e570-e581. [CrossRef] [PubMed]

95. Ha, J.H.; Jayaraman, M.; Radhakrishnan, R.; Gomathinayagam, R.; Yan, M.; Song, Y.S.; Isidoro, C.; Dhanasekaran, D.N. Differential effects of thymoquinone on lysophosphatidic acid-induced oncogenic pathways in ovarian cancer cells. J. Tradit. Complement. Med. 2020, 10, 207-216. [CrossRef] [PubMed]

96. Liu, X.; Dong, J.; Cai, W.; Pan, Y.; Li, R.; Li, B. The Effect of Thymoquinone on Apoptosis of SK-OV-3 Ovarian Cancer Cell by Regulation of Bcl-2 and Bax. Int. J. Gynecol. Cancer 2017, 27, 1596-1601. [CrossRef]

97. İnce, I.; Yıldırım, Y.; Güler, G.; Medine, E.I.; Ballıca, G.; Kuşdemir, B.C.; Göker, E. Synthesis and characterization of folic acid-chitosan nanoparticles loaded with thymoquinone to target ovarian cancer cells. J. Radioanal. Nucl. Chem. 2020, $324,1-15$. [CrossRef]

98. Johnson-Ajinwo, O.R.; Richardson, A.; Li, W.-W. Synthesis and evaluation of thymoquinone analogues as anti-ovarian can-cer agents. MDPI 2019, 22, 42.

99. Alhassani, M.Y.; Zohny, S.F.; Sheikh, R.A.; Hassan, M.A.; Kalantan, A.A.; Hosawi, S.; Alhosin, M. Thymoquinone exerts anti-tumor activities on human hepatocellular carcinoma cells: Role of angiogenesis-related genes VCAN, Grb2 and EZH2. Eur. J. Cell Sci. 2019, 10-16. [CrossRef]

100. Meral, I.; Pala, M.; Akbas, F.; Ustunova, S.; Yildiz, C.; Demirel, M. Effects of thymoquinone on liver miRNAs and oxidative stress in Ehrlich acid mouse solid tumor model. Biotech. Histochem. 2018, 93, 301-308. [CrossRef]

101. Helmy, S.A.; El-Mesery, M.; El-Karef, A.; Eissa, L.A.; El Gayar, A.M. Thymoquinone upregulates TRAIL/TRAILR2 expression and attenuates hepatocellular carcinoma in vivo model. Life Sci. 2019, 233, 116673. [CrossRef] [PubMed]

102. Haron, A.S.; Syed Alwi, S.S.; Saiful Yazan, L.; Abd Razak, R.; Ong, Y.S.; Zakarial Ansar, F.H.; Roshini Alexander, H. Cyto-toxic effect of thymoquinone-loaded nanostructured lipid carrier (TQ-NLC) on liver cancer cell integrated with hepatitis B genome, Hep3B. Evid. Based Complement Alternat. Med. 2018. [CrossRef]

103. Bashir, A.O.; El-Mesery, M.E.; Anwar, R.; Eissa, L.A. Thymoquinone potentiates miR-16 and miR-375 expressions in hepato-cellular carcinoma. Life Sci. 2020, 117794. [CrossRef] [PubMed]

104. Butt, A.S.; Nisar, N.; Ghani, N.; Altaf, I.; Mughal, T.A. Isolation of thymoquinone from Nigella sativa L. and Thymus vulgaris L., and its anti-proliferative effect on HeLa cancer cell lines. Trop. J. Pharm. Res. 2019, 18, 37. [CrossRef]

105. Li, J.; Khan, A.; Wei, C.; Cheng, J.; Chen, H.; Yang, L.; Ijaz, I.; Fu, J. Thymoquinone Inhibits the Migration and Invasive Characteristics of Cervical Cancer Cells SiHa and CaSki In Vitro by Targeting Epithelial to Mesenchymal Transition Associated Transcription Factors Twist1 and Zeb1. Molecules 2017, 22, 2105. [CrossRef]

106. Ng, W.K.; Saiful Yazan, L.; Yap, L.H.; Wan, N.H.; Wan, A.G.; How, C.W.; Abdullah, R. Thymoquinone-loaded nanostruc-tured lipid carrier exhibited cytotoxicity towards breast cancer cell lines (MDA-MB-231 and MCF-7) and cervical cancer cell lines (HeLa and SiHa). BioMed Res. Int. 2015. [CrossRef]

107. Houssein, M.; Fatfat, M.; Habli, Z.; Ghazal, N.; Mokdad, S.; Khalife, H.; Khalil, M.; Gali-Muhtasib, H. Thymoquinone syner-gizes with arsenic and interferon alpha to target human T-cell leukemia/lymphoma. Life Sci. 2020, 117639. [CrossRef] 
108. Musalli, M.G.; Hassan, M.A.; Sheikh, R.A.; Kalantan, A.A.; Halwani, M.A.; Zeyadi, M.; Hosawi, S.; Alhosin, M. Thymo-quinone induces cell proliferation inhibition and apoptosis in acute myeloid leukemia cells: Role of apoptosis-related WT1 and BCL2 genes. Eur. J. Cell Sci. 2019, 1, 2-9. [CrossRef]

109. Alaufi, O.M.; Noorwali, A.; Zahran, F.; Al-Abd, A.M.; Al-Attas, S. Cytotoxicity of thymoquinone alone or in combination with cisplatin (CDDP) against oral squamous cell carcinoma in vitro. Sci. Rep. 2017, 7, 13131. [CrossRef]

110. Kotowski, U.; Heiduschka, G.; Kadletz, L.; Fahim, T.; Seemann, R.; Schmid, R.; Schneider, S.; Mitterbauer, A.; Thurnher, D. Effect of thymoquinone on head and neck squamous cell carcinoma cells in vitro: Synergism with radiation. Oncol. Lett. 2017, 14, 1147-1151. [CrossRef]

111. Khan, A.; Tania, M.; Fu, J. Epigenetic role of thymoquinone: Impact on cellular mechanism and cancer therapeutics. Drug Discov. Today 2019, 24, 2315-2322. [CrossRef] [PubMed]

112. Yeh, S.-J.; Lin, C.-U.; Li, C.-W.; Chen, B.-S. Systems Biology Approaches to Investigate Genetic and Epigenetic Molecular Progression Mechanisms for Identifying Gene Expression Signatures in Papillary Thyroid Cancer. Int. J. Mol. Sci. 2019, $20,2536$. [CrossRef]

113. Parbin, S.; Shilpi, A.; Kar, S.; Pradhan, N.; Sengupta, D.; Deb, M.; Rath, S.K.; Patra, S.K. Insights into the molecular interac-tions of thymoquinone with histone deacetylase: Evaluation of the therapeutic intervention potential against breast cancer. Mol. Biosyst. 2016, 12, 48-58. [CrossRef] [PubMed]

114. Relles, D.; Chipitsyna, G.I.; Gong, Q.; Yeo, C.J.; Arafat, H. Thymoquinone promotes pancreatic cancer cell death and reduc-tion of tumor size through combined inhibition of histone deacetylation and induction of histone acetylation. Adv. Prev. Med. 2016. [CrossRef] [PubMed]

115. Gray, J.P.; Zayasbazan Burgos, D.; Yuan, T.; Seeram, N.; Rebar, R.; Follmer, R.; Heart, E.A. Thymoquinone, a bioactive com-ponent of Nigella sativa, normalizes insulin secretion from pancreatic $\beta$-cells under glucose overload via regulation of malo-nyl-CoA. Am. J. Physiol. 2016, 310, E394-E404.

116. Gonfloni, S.; Iannizzotto, V.; Maiani, E.; Bellusci, G.; Ciccone, S.; Diederich, M. P53 and Sirt1: Routes of metabolism and ge-nome stability. Biochem. Pharmacol. 2014, 92, 149-156. [CrossRef]

117. Zhang, Z.Y.; Hong, D.; Nam, S.H.; Kim, J.M.; Paik, Y.H.; Joh, J.W.; Kwon, C.D.; Park, J.B.; Choi, G.-S.; Jang, K.Y. SIRT1 regulates oncogenesis via a mutant p53-dependent pathway in hepatocellular carcinoma. J. Hepatol. 2015, 62, 121-130. [CrossRef]

118. Karandrea, S.; Yin, H.; Liang, X.; Slitt, A.L.; Heart, E.A. Thymoquinone ameliorates diabetic phenotype in Diet-Induced Obe-sity mice via activation of SIRT-1-dependent pathways. PLoS ONE 2017, 12. [CrossRef]

119. D'Onofrio, N.; Servillo, L.; Balestrieri, M.L. SIRT1 and SIRT6 Signaling Pathways in Cardiovascular Disease Protection. Antioxid. Redox Signal. 2018, 28, 711-732. [CrossRef]

120. Lu, Y.; Feng, Y.; Liu, D.; Zhang, Z.; Gao, K.; Zhang, W.; Tang, H. Thymoquinone Attenuates Myocardial Ischemia/Reperfusion Injury Through Activation of SIRT1 Signaling. Cell. Physiol. Biochem. 2018, 47, 1193-1206. [CrossRef]

121. Alhosin, M. Thymoquinone is a novel potential inhibitor of SIRT1 in cancers with p53 mutation: Role in the reactivation of tumor suppressor p73. World Acad. Sci. J. 2020, 2, 1. [CrossRef]

122. Khan, M.D.; Zheng, M.; Fu, J. Epigenetic modification of oncogenes or tumor suppressor genes by thymoquinone in triple negative breast cancer. $A A C R$ 2019. [CrossRef]

123. Li, Y.-Y.; Tao, Y.W.; Gao, S.; Li, P.; Zheng, J.-M.; Zhang, S.-E.; Liang, J.; Zhang, Y. Cancer-associated fibroblasts contribute to oral cancer cells proliferation and metastasis via exosome-mediated paracrine miR-34a-5p. EBioMedicine 2018, 36, 209-220. [CrossRef] [PubMed]

124. Ikwegbue, P.C.; Masamba, P.; Oyinloye, B.E.; Kappo, A.P. Roles of Heat Shock Proteins in Apoptosis, Oxidative Stress, Human Inflammatory Diseases, and Cancer. Pharmaceuticals 2017, 11, 2. [CrossRef]

125. Hossen, M.J.; Yang, W.S.; Kim, D.; Aravinthan, A.; Kim, J.-H.; Cho, J.Y. Thymoquinone: An IRAK1 inhibitor with in vivo and in vitro anti-inflammatory activities. Sci. Rep. 2017, 7, srep42995. [CrossRef]

126. Elsherbiny, N.M.; Maysarah, N.M.; El-Sherbiny, M.; Al-Gayyar, M.M. Renal protective effects of thymoquinone against so-dium nitrite-induced chronic toxicity in rats: Impact on inflammation and apoptosis. Life Sci. 2017, 180, 1-8. [CrossRef]

127. Amin, B.; Hosseinzadeh, H. Black cumin (Nigella sativa) and its active constituent, thymoquinone: An overview on the anal-gesic and anti-inflammatory effects. Planta Med. 2016, 82, 8-16. [CrossRef]

128. Abdel-Daim, M.M.; Sayed, A.A.; Abdeen, A.; Aleya, L.; Ali, D.; Alkahtane, A.A.; Alarifi, S.; Alkahtani, S. Piperine enhances the antioxidant and anti-inflammatory activities of thymoquinone against microcystin-LR-induced hepatotoxicity and neu-rotoxicity in mice. Oxid. Med. Cell Longev. 2019. [CrossRef]

129. Amartey, J.; Gapper, S.; Hussein, N.; Morris, K.; Withycombe, C.E. Nigella sativa Extract and Thymoquinone Regulate Inflammatory Cytokine and TET-2 Expression in Endothelial Cells. Artery Res. 2019, 25, 157-163. [CrossRef]

130. Fan, Z.; Duan, J.; Wang, L.; Xiao, S.; Li, L.; Yan, X.; Yao, W.; Wu, L.; Zhang, S.; Zhang, Y.; et al. PTK2 promotes cancer stem cell traits in hepatocellular carcinoma by activating Wnt/ $\beta$-catenin signaling. Cancer Lett. 2019, 450, 132-143. [CrossRef]

131. Jiao, Q.; Bi, L.; Ren, Y.; Song, S.; Wang, Q.; Wang, Y.-S. Advances in studies of tyrosine kinase inhibitors and their acquired resistance. Mol. Cancer 2018, 17, 1-12. [CrossRef] [PubMed]

132. Carneiro, D.M.; Silveira, C.D.; Rezende, A.S.; Silva, R.O.; Crema, V.O. Tyrosine kinase inhibitor TKI-258 inhibits cell motility in oral squamous cell carcinoma in vitro. J. Oral Pathol. Med. 2017, 46, 484-488. [CrossRef] 
133. Tong, Y.; Huang, C.; Zhang, J. A novel EGFR-TKI inhibitor (cAMP-H3BO3complex) combined with thermal therapy is a promising strategy to improve lung cancer treatment outcomes. Oncotarget 2017, 8, 56327. [CrossRef]

134. Botting, G.M.; Rastogi, I.; Chhabra, G.; Nlend, M.; Puri, N. Mechanism of Resistance and Novel Targets Mediating Resistance to EGFR and c-Met Tyrosine Kinase Inhibitors in Non-Small Cell Lung Cancer. PLoS ONE 2015, 10, e0136155. [CrossRef] [PubMed]

135. Namba, K.; Shien, K.; Yoshioka, T.; Torigoe, H.; Sato, H.; Yamamoto, H.; Soh, J.; Tsukuda, K.; Toyooka, S. Abstract 3156: Multiple acquired resistance mechanisms against third generationEGFR-TKI osimeritinib in non-smal cell lung cancer cells. Exp. Mol. Ther. 2017, 77, 3156. [CrossRef]

136. Chen, M.; Zang, M.; Guo, X. MicroRNA-106a-5p functions as an oncogene via regulating PTEN in breast cancer cells. Int. J. Clin. Exp. Med. 2019, 12, 8044-8056.

137. Ni, J.; Zhou, L.-L.; Ding, L.; Zhao, X.; Cao, H.; Fan, F.; Li, H.; Lou, R.; Du, Y.; Dong, S.; et al. PPAR $\gamma$ agonist efatutazone and gefitinib synergistically inhibit the proliferation of EGFR-TKI-resistant lung adenocarcinoma cells via the PPAR $\gamma /$ PTEN/Akt pathway. Exp. Cell Res. 2017, 361, 246-256. [CrossRef] [PubMed] 